\title{
Analisa Risiko Proses Fisioterapi Dan Mitigasi Menggunakan Metode Workload Indicator Of Staffing Need (Tinjauan: Proses Internal dan Manusia di Rumah Sakit X)
}

Oleh:

\author{
Novlinda Susy Anrianawati Manurung, M.M
}

Dr. Indra Gunawan, ST., ME

\section{ABSTRAK}

Penelitian dilakukan dengan latar belakang, adanya Keputusan Menteri Kesehatan No.65 Tahun 2015 tentang standar pelayanan fisioterapi yang digunakan sebagai dasar manajemen risiko dalam mempersiapkan strategi untuk mengantisipasi kejadian yang tidak diharapkan muncul pada penatalaksanaan proses fisioterapi.Keputusan Menteri Kesehatan Nomor:8I/ MENKES/SK/2004, tentang Pedoman Penyusunan Perencanaan SDM Kesehatan di Tingkat Propinsi, Kabupaten/Kota serta Rumah Sakit untuk menghitung kebutuhan SDM di Rumah Sakit, yaitu workload indicator staffing need (WISN)sebagai strategi pengambilan kebijakan.

Penelitian ini bertujuan untuk meningkatkan mutu pelayanan fisioterapi melalui perhitungan risiko proses fisioterapi dan tindakan mitigasi risiko menggunakan metode Workload Indicator Staffing Need.

Penelitian menggunakan Metode tahapan manajemen risiko sebagai metode analisisnya dan WISN sebagai metode untuk mitigasi risiko. Analisis risiko diawali dengan identifikasi risiko kemudian mengukur risiko dengan menghitung peluang dan dampak dari risiko tersebut dan merancang manajemen risiko sebagai mitigasinya. Berdasarkan penelitian yang telah dilakukan diperoleh kejadian dengan risiko tertinggi 25 pada tahap pemeriksaan dan pengukuran dengan peluang tidak memiliki waktu yang memadai untuk pemeriksaan dan pengukuran fisioterapi dengan nilai 5 dan dampak penulisan laporan hasil pemeriksaan tidak lengkap dengan nilai 5 pada tahap dokumentasi, sedangkan pada tahap intervensi fisioterapi terjadi peluang pengurangan jenis dan waktu intervensi dengan nilai 5 dan dampak berupa penyembuhan yang lama atau tidak sembuh (cacat) mendapat nilai 5 sehingga didapat nilai risiko 25 .

Adapun pemicu terjadinya potensi risiko adalah jumlah pasien (rata-rata 5060/hari) yang tidak sebanding dengan jumlah tenaga fisioterapis (4 orang) serta kurangnya sarana alat intervensi fisioterapi (penatalaksanaan alat menggunakan dosis waktu min : I5 menit).

Dalam Penelitian ini dapat disimpulkan bahwa untuk meningkatkan mutu pelayanan fisioterapi sesuai dengan PMK 65 tahun 20 I5, maka langkah strategis yang harus dilakukan adalah pengambilan kebijakan mitigasi kejadian yang tidak diharapkan muncul dengan menurunkan peluang, seperti: menambah jumlah tenaga fisioterapissesuai dengan kebijakan pemerintah dalam Keputusan Menteri Kesehatan Nomor : 8I /MENKES/ SK/2004, tentang Pedoman Penyusunan Perencanaan SDM Kesehatan di Tingkat Propinsi, Kabupaten/Kota serta Rumah Sakit untuk menghitung kebutuhan SDM di Rumah Sakit, yaitu workload indicator staffing need (WISN), mengatur jadwal pemisahan hari pemeriksaan 
pengukuran fisioterapi dengan hari pelaksanaan intervensi dan menambah jumlah alat intervensi fisioterapi.

Kata kunci : Analisis risiko, proses fisioterapi, mitigasi risiko, workload indicatorstaffing need

\section{BAB I \\ PENDAHULUAN}

\section{I.I Latar Belakang Masalah}

Rumah Sakit sebagai pusat pelayanan kesehatan dalam melaksanakan tugasnya untuk meningkatkan mutu pelayanan serta kualitas kesehatan menggunakan sumber daya manusia atau tenaga kerja kesehatan pada setiap unit usahanya. Berdasarkan tujuan tersebut, maka menurut llyas (2004) upaya penting yang harus dilakukan pimpinan rumah sakit adalah merencanakan kebutuhan SDM secara tetap sesuai dengan fungsi pelayanan setiap unit, bagian dan instalasi rumah sakit. SDM kesehatan merupakan tiang penopang atau penyangga upaya kesehatan harus selalu dikembangkan dan diberdayakan. Peran sumber daya manusia (SDM) didalam sebuah perusahaan atau rumah sakit sangat penting karena SDM yang melakukan seluruh kegiatan dalam rangka memenuhi tujuan dari perusahaan atau rumah sakit.Setiap sumberdaya dalam melaksanakan tugas maupun fungsinya pada unit usaha atau pelayanannya memiliki tahapan proses kerja sesuai profesi masingmasing. Salah satu sumber daya tenaga kerja yang ada di rumah sakit adalah fisioterapis. Sebagai profesi yang menjalankan kegiatan pelayanan fisioterapi maka seorang fisioterapis memiliki acuan sebagai dasar melaksanakan tugas dan fungsinya.

Peraturan Menteri Kesetahan no 65 tahun 2015 tentang standar pelayanan fisioterapi yang merupakan acuan dan dasar dalam melaksanakan tugas fungsi fisioterapis telah menetapkan standar pelayanan tenaga fisioterapi di rumah sakit untuk menetapkan kebutuhan tenaga fisioterapi berdasarkan kualifikasi dan jenis pelayanan fisioterapi di rumah sakit. Pengaturan Standar Pelayanan Fisioterapi bertujuan untuk memberikan acuan bagi penyelenggaraan pelayanan fisioterapi yang bermutu dan dapat dipertanggungjawabkan. Rumah sakit dalam menjalankan pelayanan kesehatan harus mengacu pada standar pelayanan untuk mitigasi risiko. Standar
Pelayanan Fisioterapi meliputi penyelenggaraan pelayanan, manajemen pelayanan, dan sumber daya manusia yang disebut fisioterapis.Fasilitas pelayanan kesehatan seperti rumah sakit bertanggungjawab terhadap pemenuhan kebutuhan kualifikasi fisioterapis yang sesuai, termasuk pada kebutuhan pendidikan dan pelatihan dalam rangka pengembangan profesionalisme serta pelayanan. Pemenuhan sumber daya manusia fisioterapis di fasilitas pelayanan kesehatan dilakukan berdasarkan analisis beban kerja dan/atau rasio pelayanan pasien/klien per hari kerja (I fisioterapis : 8-I0 pasien/klien per hari kerja) dengan mempertimbangkan kebutuhan kualifikasi fisioterapis yang sesuai.

Berdasarkan standar pelayanan fisioterapi maka harus dilihat apa saja yang merupakan unsur daripada beban kerja fisioterapis yang terdapat dalam proses fisioterapi. Dalam penatalaksanaan proses fisioterapi terdapat beberapa tahap tindakan seperti: Assesmen pasien, Penegakan Diagnosis, Perencanaan intervensi, Intervensi, Evaluasi/Re-Evaluasi, Komunikasi dan Edukasi serta Dokumentasi. Pada setiap pelaksanaan tahapan tindakan fisioterapi dibutuhkan waktu yang relatif besar, terutama pada tahap assesmen serta penegakan diagnosa yang berfungsi untuk mendapatkan data akurat sebagai dasar pemberian tindakan, kemudian dalam tahap intervensi secara keseluruhan menggunakan ukuran waktu sebagai dosis intervensi yang juga membutuhkan masa yang cukup besar. Sejak pelaksanaan tahap assesmen hingga evaluasi, fisioterapis juga harus melaksanakan tahap penulisan laporan secara bersamaan yang berfungsi untuk mendokumentasikan data dan menjadi dasar serta bagian terpenting dalam memenuhi tahap terakhir yang disebut dokumentasi fisioterapi. Proses dokumentasi data mencantumkan seluruh aktifitas yang telah dilaksanakan pada setiap tahap yang terdapat dalam proses fisioterapi. Dokumentasi proses fisioterapi berfungsi sebagai alat informasi terintegrasi dari fisioterapis kepada seluruh tenaga kesehatan yang terkait dalam proses penanganan seorang pasien. Dokumentasi juga merupakan alat yang akurat dalam memberkan informasi kualitas kerja serta sebagai alat perlindungan hukum bagi seorang fisioterapis. Dengan dilaksanakannya sistim Jaminan Kesehatan Nasional oleh pemerintah untuk mewujudkan amanat UUD 1945 no 28 bagian $\mathrm{H}$, maka terjadi peningkatan jumlah pasien di 
unit instalasi rehabilitasi medik dengan tenaga pelaksana pelayanan adalah seorang fisioterapis. Peningkatan jumlah pasien sangat berhubungan dengan peningkatan jumlah waktu pelayanan per hari di rumah sakit. Untuk menghindari penurunan kualitas pelayanan dengan adanya peningkatan jumlah pasien maka perlu dianalisis kebutuhan tenaga fisioterapis yang dibutuhkan sehubungan dengan beban kerja serta lamanya waktu pelaksanaan proses fisioterapi dalam satu hari kerja.

Kebutuhan tenaga fisioterapis dapat dianalisis melalui pengukuran besarnya beban kerja fisioterapi dengan menggunakan metode "workload indicator of staffing need"(WISN). Metode WISN menggunakan ukuran waktu kerja sebagai indikator penilaian pada setiap tahap proses kerja sumber daya manusia.WISN adalah sebuah alat yang dipakai untuk mengukur beban kerja tenaga kesehatan yang di keluarkan oleh WHO. Metode ini digunakan untuk menetapkan standar kepatutan jumlah tenaga kerja yang dibutuhkan pada setiap unit kerja. Pemenuhan kebutuhan tenaga kerja yang sesuai akan meningkatkan kinerja, mutu pelayanan dan mitigasi risiko pelayanan.

\section{I.2 Rumusan Masalah}

I) Bagaimana penatalaksanaan proses fisioterapi di Rumah Sakit $X$ sehubungan dengan peningkatan jumlah pasien BPJS?

2) Bagaiman risiko penatalaksanaan proses fisioterapi di Rumah Sakit X sehubungan dengan peningkatan jumlah pasien BPJS?

3) Bagaimana kebijakan yang diberikan untuk mitigasi risiko di Rumah Sakit $X$ sehubungan dengan peningkatan jumlah pasien BPJS?

\section{I.3 Tujuan Penelitian}

Berdasarkan rumusan masalah maka tujuan dari penelitian ini adalah untuk menganalisis tentang:

I) Identifikasi penatalaksanaan proses fisioterapi di Rumah Sakit X

2) Identifikasi kejadian yang tidak diharapkan muncul dalam penatalaksanaan proses fisioterapi

3) Mengukur Risiko dalam penatalaksanaan proses fisioterapi di Rumah Sakit X
4) Membuat kebijakan mitigasi risiko dalam penatalaksanaan proses fisioterapi di Rumah Sakit $X$

\section{I.4 Ruang Lingkup}

Pada penelitian ini dibahas tentang analisis risiko penatalaksanaan proses fisioterapi sehubungan dengan peningkatan jumlah pasien BPJS dan keberadaan sarana alat intervensi fisioterapi serta kebutuhan tenaga fisioterapis yang sesuai dengan standar pelayanan di unit Instalasi Rehabilitasi Medik Rumah Sakit X.

\section{I.5 Manfaat Penelitian}

I) Rumah sakit pada umumnya dan unit fisioterapi secara khusus dapat membuat kebijakan tentang manajemen risiko dalam pelaksanaan tahapan tindakan fisioterapi yang sesuai dengan prosedur proses pelayanan fisioterapi.

2) Rumah Sakit pada umumnya dan unit fisioterapi secara khusus dapat melaksanakan manajemen risiko (mengidentifikasi, memetakan, mendokumentasikan, mengukur serta mengendalikan risiko) dalam pelayanan fisioterapi.

3) Rumah Sakit mendapatkan informasi tentang kebutuhan fisioterapis yang sesuai dengan standar pelayanan fisioterapi dan memenuhi jumlah sumber daya berdasarkan pengukuran kebutuhan tenaga fisioterapi melalui metode Workload Indicator of Staffing Need.

\section{LANDASAN TEORI}

\section{I. Sumber Daya Manusia}

Sumber Daya Manusia atau Tenaga kerja dalam suatu institusi, perusahaan atau organisasi menurut Samsudin (2006) adalah orang-orang yang merancang dan menghasilkan barang dan jasa, mengawasi mutu, memasarkan produk, mengalokasikan sumber daya finansial, serta merumuskan seluruh strategi dan tujuan organisasi.

\subsection{Manajemen Sumber Daya Manusia}

Menurut M Manulang (1974) manajemen sumber 
daya manusia sebagai ilmu dan seni perencanaan, pelaksanaan dan pengawasan, tenaga kerja untuk tercapainya tujuan organisasi dengan adanya kepuasan hati dari para pekerja

Menurut Notoatmodjo (2003), manajemen sumber daya manusia adalah penarikan, seleksi, pengembangan, pemeliharaan, dan penggunaan sumber daya untuk mencapai tujuan-tujuan individu maupun organisasi.

\subsection{Tujuan Manajemen Sumber Daya Manusia}

Dilihat dari tujuannya maka manajemen sumber daya manusia menurut Samsudin (2006), adalah memperbaiki kontribusi produktif orang-orang atau tenaga kerja terhadap organisasi atau perusahaan dengan cara yang bertanggungjawab secara strategis, etis dan sosial.

Empat tujuan manajemen sumber daya manusia, adalah:

a. Tujuan sosial dimana organisasi atau perusahaan bertanggungjawab secara sosial dan etis terhadap kebutuhan dan tantangan masyarakat dengan meminimalkan dampak negatifnya, organisasi atau perusahaan bisnis diharapkan dapat meningkatkan kualitas masyarakat dan dapat membantu memecahkan masalahmasalah sosial.

b. Tujuan organisasional adalah sasaran formal yang dibuat untuk membantu organisasi mencapai tujuannya.

c. Tujuan fungsional adalah tujuan untuk mempertahankan kontribusi departemen sumber daya manusia pada tingkat yang sesuai dengan kebutuhan organisasi.

d. Tujuan individual adalah tujuan pribadi dari tiap anggota organisasi yang hendak dicapai melalui aktifitasnya dalam organisasi.

\subsection{Perencanaan Sumber Daya Manusia}

Perencanaan adalah sebuah kegiatan yang merupakan tugas serta fungsi dari manajemen dalam mengurangi ketidakpastian di masa yang akan datang, dengan melakkukan seleksi berbagai alternative tujuan, kebijakan, prosedur serta berbagai program (Handoko, 2008).
Perencanaan sumber daya manusia merupakan serangkaian kegiatan yang dilakukan untuk mengantisipasi permintaan-permintaan bisnis dan lingkungan pada organisasi di waktu yang akan datang dan untuk memenuhi kebutuhan-kebutuhan tenaga kerja yang ditimbulkan oleh kondisi-kondisi tersebut (Handoko, 1987).

Perencanaan sumber daya manusia merupakan hal yang mutlak diperlukan, bukan hanya karna setiap organisasi pasti menghadapi masa depan yang selalu “diselimuti” oleh ketidakpastian, akan tetapi juga karena sumber daya yang dimiliki atau mungkin dimiliki selalu terbatas, padahal tujuan yang ingin dicapai per definisi selalu tidak terbatas (Siagian, 2006 dan dikutip dari Wijono, 1997).

Salah satu manfaat dari enam manfaat perencanaan sumber daya manusia menurut Siagian (2006), adalah bahwa perencanaan sumber daya manusia berkaitan dengan penentuan kebutuhan tenaga kerja dimasa yang akan datang, baik dalam arti jumlah dan kualifikasinya untuk mengisi berbagai jabatan dan menyelenggarakan berbagai aktifitas baru kelak.

Analisis kebutuhan pegawai merupakan suatu proses analisis yang logis dan teratur untuk mematuhi jumlah dan kualitas pegawai yang diperlukan dalam suatu unit organisasi.Tujuan analisis adalah agar setiap pegawai pada semua unit organisasi mendapatkan pekerjaan yang sesuai dengan tugas dan wewenang tanggung jawabnya (dikutip dari Benhard R. L. Paruntu, 20I5)

Analisis jumlah sumber daya manusia dalam suatu perusahaan (rumah sakit) adalah sesuatu yang lazim dilakukan. Hal ini diperlukan untuk menentukan jumlah sumber daya yang optimal untuk menjalankan proses bisnis dalam masing masing unit atau departeman di dalam perusahaan (rumah sakit).

\subsection{Fisioterapi}

Fisioterapis adalah sumber daya manusia atau tenaga kerja dalam bidang kesehatan yang telah lulus pendidikan fisioterapi sesuai ketentuan peraturan perundang-undangan (Permenkes no. 65 tahun 20I5)

Dalam pelayanan kesehatan, organisasi perdagangan dunia (WTO) dalam putaran Uruguay 19861994 mencatat fisioterapis termasuk jasa professional dalam perdagangan bebas dunia. 
Fisioterapis sebagai profesi sebagaimana disosialisasikan oleh WHO tentang Classifying Health Worker pada The International Standard Classification of Occupation (ISCO 2008) tercatat dalam occupation group sebagai physiotherapy dengan ISCO Code 2264.

Fisioterapis Indonesia memiliki kualifikasi dan kewenangan yang telah diatur dalam Peraturan Menteri Kesehatan No. 80 Tahun 2013, sebagai berikut :

I) Fisioterapis Ahli Madya merupakan lulusan Program Diploma Tiga Fisioterapi sesuai dengan ketentuan peraturan perundang-undangan

2) Fisioterapis Sarjana Sains Terapan merupakan lulusan Program Diploma Empat atau Sarjana Terapan Fisioterapi sesuai dengan ketentuan peraturan perundang-undangan

3) Fisioterapis Profesi merupakan lulusan Program Profesi Fisioterapi sesuai dengan ketentuan peraturan perundang-undangan

4) Fisioterapis Spesialis merupakan lulusan Program Spesialis Fisioterapi sesuai dengan ketentuan peraturan perundang-undangan

Pada BAB II Bagian pertama pasal 6 ayat I sampai 5 dari Peraturan Menteri Kesehatan No. 80 tahun 2013 tentang Surat ljin Praktik Fisioterapi juga diatur tentang status kemandirian praktik fisioterapi, sebagai berikut: I) Fisioterapis dapat menjalankan praktik pelayanan Fisioterapi secara mandiri ataubekerja di Fasilitas Pelayanan Kesehatan.

2) Fisioterapis yang menjalankan praktik pelayanan Fisioterapi secara mandiri sebagaimana dimaksud pada ayat (I) harus merupakan Fisioterapis Profesi atau Fisioterapis Spesialis.

3) FisioterapisAhli Madya atau Fisioterapis Sains Terapan hanya dapat bekerja di Fasilitas Pelayanan Kesehatan.

4) Fisioterapis Ahli Madya atau Fisioterapis Sains Terapan sebagaimana dimaksud pada ayat 3 , harus bekerja di bawah pengawasan Fisioterapis Profesi atau Fisioterapis Spesialis.

5) Dalam hal tidak terdapat Fisioterapis Profesi atau Fisioterapis Spesialis, Fisioterapi

Ahli Madya atau Fisioterapis Sains Terapan dapat melakukan Pelayanan Fisioterapi secara berkolaborasi dengan tenaga kesehatan lain yang ada di Fasilitas Pelayanan Kesehatan tempat Fisioterapis Ahli Madya atau Fisioterapis Sains Terapan yang bersangkutan bekerja.

\subsection{Standar Pelayanan Fisioterapi}

Berdasarkan Peraturan Menteri Kesehatan No.65 tahun 2015 (PMK 65 tahun 20I5) tentang standar pelayanan fisioterapi maka diatur prosedur pelaksanaan proses pelayanan fisioterapi dalam pasal 3 sebagai berikut:

I) Standar Pelayanan Fisioterapi meliputi penyelenggaraan pelayanan, manajemen pelayanan, dan sumber daya.

2) Standar Pelayanan Fisioterapi sebagaimana dimaksud pada ayat (I) harus diterapkan dalam pemberian pelayanan kepada pasien/klien pada semua kasus.

3) Penatalaksanaan pada masing-masing kasus disusun oleh Organisasi Profesi dan disahkan oleh Menteri

4) Ketentuan lebih lanjut mengenai Standar Pelayanan Fisioterapi sebagaimana dimaksud pada ayat (I) tercantum dalam Lampiran yang merupakan bagian tidak terpisahkan dari Peraturan Menteri ini.

\subsection{Sarana Alat Fisioterapi}

Peralatan intervensi memiliki batas waktu penggunaan atau penerapan yang merupakan bagian dari dosis terapi sesuai dengan jenis alat maupun jenis penyakit.

Berdasarkan tulisan, Barbara (2006) maka dapat dilihat bahwa penggunaan peralatan intervensi seperti Ultrasound adalah 8-10 menit dengan temperatur $40^{\circ}$ $C$ dan intensitas sebesar $1-1,5 \mathrm{~W} / \mathrm{cm}^{2}$, sedangkan Micro Wave Diathermy maupun Short Wave Diathermy adalah Persiapan alat, tes alat, pre pemanasan 5-10 menit kemudian dilanjutkan dengan 20-30 menit dengan intensitas $50-100 \mathrm{~W} / \mathrm{cm}^{2}$ adapun alat Transcutanaeus Electrcal Nerve Stimulation penggunaan selama 30 menit menurut Parjoto (2006)

\subsection{Workload Indicator of Staffing Need (WISN)}

Untuk dapat merencanakan sumber daya manusia perlu diketahui terlebih dahulu jumlah SDM yang dibutuhkan. Berdasarkan kebutuhan tersebut dapat direncanakan apakah jumlah yang ada saat ini telah mencukupi atau kekurangan. Dalam menganalisis kebutuhan tenaga kerja digunakan alat untuk mengukur beban kerja SDM. 
Beban Kerja fisioterapis adalah seluruh kegiatan atau aktifitas yang dilakkukan oleh fisioterapis selama tugas di suatu unit pelayanan fisioterapi.

Metode yang digunakan sebagai alat ukur beban kerja bagi tenaga kesehatan, adalah Workload Indicator of Staffing Need.Alat ini dalam penerapannya menggunakan analisis lamanya waktu dalam melaksanakan sebuah aktifitas kerja dari setiap SDM sesuai dengan tugas dan fungsi profesinya.

Metode WISN membantu untuk menentukan berapa banyak tenaga kerja kesehatan tipe tertentu dibutuhkan sesuai dengan beban kerja yang diberikan atau terdapat pada fasilitas kesehatan serta mengukur tekanan beban kerja dari tenaga kerja kesehatan pada fasilitas kesehatan tersebut. Metode WISN menggunakan data yang tersedia pada sistim informasi kesehatan serta memberikan pilihan untuk menutup celah dari ketersediaan atau keberadaan kekuatan pekerja. Hal ini tergantung pada penyediaan kemasan pelayanan kesehatan yang berbeda serta kompleksitas perawatan dengan penetapan fasilitas kesehatan yang berbeda-beda.

Aplikasi WISN adalah perangkat lunak yang menjadi alat rekam data, analisis, dan pelaporan data yang berhubungan dengan status tenaga kesehatan serta fasilitas kesehatan yang dibutuhkan.

Pedoman penggunaan perangkat lunak WISN menjelaskan tentang gambaran dari aplikasi, dan memberikan instruksi tahap demi tahap untuk memenuhi atau melengkapi berbagai variasi tugas atau kebutuhan data. Adapun tugas atau data yang akan dianalisis serta diukur dalam WISN terdiri dari: fasilitas (sarana), fasilitas tenaga kerja, waktu yang dibutuhkan untuk melakukan pekerjaan, statistik beban kerja, standar aktifitas, perbandingan tenaga kerja, perhitungan biaya remunerasi (WHO, 20I6).

Metode WISN adalah alat yang ditetapkan dalam Keputusan Menteri Kesehatan Nomor:8I/ MENKES/ SK/ 2004 tentang Pedoman Penyusunan Perencanaan SDM Kesehatan di Tingkat Propinsi, Kabupaten/Kota serta Rumah Sakit untuk menghitung kebutuhan SDM di Rumah Sakit.

Melalui penerapan metode WISN dapat diketahui unit kerja dan kategori SDM nya, waktu kerja tersedia tiap kategori SDM, standar beban kerja, standar kelonggaran, kuantitas kegiatan pokok dan akhirnya dapat mengetahui kebutuhan SDM pada unit kerja tersebut.

Data yang dibutuhkan dalam menetapkanwaktu kerja tersedia atau hari kerja, adalah;

a. Hari kerja dalam satu tahun (A)

b. Cuti tahunan (B)

c. Diklat (C)

d. Hari libur nasional/cuti bersama (D)

e. Ketidakhadiran karena sakit atau ijin (E)

f. Waktu kerja efektif dalam satu hari (F)

\section{Rumus waktu tersedia adalah :}

$(A-(B+C+D+E)) \times F$

Standar beban kerja merupakan volume atau kuantitas beban kerja dalam satu tahun dari tiap kategori SDM, yang disusun berdasarkan waktu yang dibutuhkan untuk menyelesaikan (rata-rata waktu) dan waktu yang tersedia atau yang dimiliki oleh masing-masing kategori SDM.

\section{Beban kerja terdiri dari :}

a. Kegiatan pokok yang dilaksanakan

b. Rata-rata waktu yang dibutuhkan untuk menyelesaikan tiap kegiatan pokok

c. Standar beban kerja/ tahun

\section{Rata-rata waktu terdiri dari :}

a. Waktu yang dibutuhkan untuk suatu kegiatan pokok oleh masingmasing tenaga SDM.

b. Kebutuhan waktu untuk menyelesaikan kegiatan sangat bervariasi dan dipengaruhi: standar pelayanan, SOP, sarana prasarana yang tersedia dan kompetensi SDM

c. Ditetapkan berdasarkan pengamatan dan pengalaman selama bekerja dan kesepakatan bersama.

d. Sebaiknya ditetapkan berdasarkan waktu yang dibutuhkan untuk menyelesaikan tiap kegiatan pokok oleh SDM yang memiliki kompetensi, kegiatan pelaksanaan, standar pelayanan, SOP dan memiliki etos kerja yang baik

Rumus perhitungan Standar beban kerja adalah:

Standar beban kerja = waktu kerja yang tersedia Rata-rata waktu per kegiatan pokok 
Standar Kelonggaran bertujuan untuk memperoleh faktor kelonggaran tiap kategori SDM yang meliputi jenis kegiatan dan kebutuhan waktu untuk menyelesaikan suatu kegiatan yang tidak terkait langsung atau dipengaruhi tinggi rendahnya kualitas atau jumlah kegiatan pokok atau pelayanan. Penyusunan faktor kelonggaran dapat dilaksanakan melalui pengamatan dan wawancara kepada tiap kategori tentang kegiatan-kegiatan yang tidak terkait langsung dengan pelayanan pada pasien, misalnya rapat, penyusunan laporan kegiatan, menyusun kebutuhan habis pakai; frekuensi kegiatan dalam satu hari, minggu, bulan, serta waktu yang dibutuhkan untuk menyelesaikan kegiatan.

Rumus menyusun standar kelonggaran :

\section{Standar kelonggaran = rata-rata waktu kelonggaran Waktu kerja tersedia}

Dalam menghitung kebutuhan SDM,sumber data yang dibutuhkan adalah:
a. Waktu kerja tersedia
b. Standar beban kerja
c. Standar kelonggaran Rumusnya adalah:

\section{Kebutuhan SDM = \\ Kuantitas kegiatan pokok xStandar kelonggaran Standar beban kerja}

\subsection{Manajemen Risiko}

Definisi manajemen risiko adalah aktivitas yang terkoordinasi untuk mengarahkan dan mengendalikan sebuah organisasi dalam menangani risiko (ISO 31000:2009)

Manajemen risiko adalah proses pengelolaan risiko yang mencakup identifikasi, evaluasi dan pengendalian risiko yang dapat mengancam kelangsungan usaha atau aktivitas perusahaan.

Pengertian manajemen resiko menurut Djohanputro $(2008 ; 43)$ Manajemen resiko merupakan proses terstruktur dan sistematis dalam mengidentifikasi, mengukur, memetakan, mengembangkan alternatif penanganan resiko, dan memonitor dan mengendalikan penanganan resiko.
Pengertian manajemen risiko menurut Fachmi (2010:2) adalah suatu bidang ilmu yang membahas tentang bagaimana suatu organisasi menerapkan ukuran dalam memetakan berbagai permasalahan yang ada dengan menempatkan berbagai pendekatan manajemen secara komprehensif dan sistematis.

\subsection{Prinsip - Prinsip Manajemen Risiko}

ISO 31000 merupakan suatu standar implementasi manajemen risiko yang diterbitkan oleh International Organization for Standardization pada tanggal I3 November 2009. Standar ini ditujukan untuk dapat diterapkan dan disesuaikan untuk semua jenis organisasi dengan memberikan struktur dan pedoman yang berlaku generik terhadap semua operasi yang terkait dengan manajemen risiko.Karena sifatnya yang generik untuk implementasi terhadap manajemen resiko di suatu bidang misalnya Teknologi Informasi maka perlu memasukkan konteks Teknologi Informasi. Selain itu penerapannya dengan series ISO tentang keamanan lainnya (misal ISO 27039:20I 5 yang membahas Intrusion Detection and Preventing System) akan sangat baik.

Selanjutnya ISO 3 1 000:2009 mensyaratkan dalam implementasi manajemen risiko yang efektif harus patuh pada II prinsip sebagai berikut:

I) Manajemen risiko menciptakan nilai tambah (creates value)

Manajemen risiko memiliki kontribusi terhadap pencapaian tujuan organisasi dan peningkatan, antara lain, kesehatan dan keselamatan manusia, kepatuhan terhadap hukum dan peraturan, penerimaan publik, perlindungan lingkungan, kinerja keuangan, kualitas produk, efisiensi operasi, serta tata kelola dan reputasi perusahaan.

Misal : control penerapan handkey di kantor akan menambah nilai kedisiplinan kehadiran pegawai

2) Manajemen risiko adalah bagian integral proses dalam organisasi (an integral part of organizational processes)

Manajemen risiko adalah bagian tanggung jawab manajemen dan merupakan suatu bagian integral dalam proses normal organisasi seperti juga merupakan bagian dari seluruh proses proyek 
dan manajemen perubahan. Manajemen risiko bukanlah merupakan aktivitas yang berdiri sendiri yang terpisah dari aktivitas-aktivitas utama dan proses dalam organisasi.

Misal : control penerapan larangan keluar kantor tanpa izin di jam kantor harus selaras dengan tujuan organisasi dan mengikat seluruh pegawai

3) Manajemen risiko adalah bagian dari pengambilan keputusan (part ofdecision making)

Manajemen risiko membantu pengambil keputusan mengambil keputusan dengan informasi yang cukup. Manajemen risiko dapat membantu memprioritaskan tindakan dan membedakan berbagai pilihan alternatif tindakan.Pada akhirnya, manajemen risiko dapat membantu memutuskan apakah suatu risiko dapat diterima atau apakah suatu penanganan risiko telah memadai dan efektif.

Misal: Hasil dari pengukuran risiko (Risk Assessment) dapat membantu organisasi dalam pengambilan keputusan

4) Manajemen risiko secara eksplisit menangani ketidakpastian (explicitly addresses uncertainty)

Manajemen risiko menangani aspek-aspek ketidakpastian dalam pengambilan keputusan, sifat alami dari ketidakpastian itu, dan bagaimana menanganinya. 5) Manajemen risiko bersifat sistematis, terstruktur, dan tepat waktu (systematic, structured and timely)

Suatu pendekatan sistematis, tepat waktu, dan terstruktur terhadap manajemen risiko memiliki kontribusi terhadap efisiensi dan hasil yang konsisten, dapat dibandingkan, serta andal.

6) Manajemen risiko berdasarkan informasi terbaik yang tersedia (based on the best available information)

Masukan untuk proses pengelolaan risiko didasarkan oleh sumber informasi seperti pengalaman, umpan balik, pengamatan, prakiraan, dan pertimbangan pakar. Meskipun demikian, pengambil keputusan harus terinformasi dan harus mempertimbangkan segala keterbatasan data atau model yang digunakan atau kemungkinan perbedaan pendapat antar pakar.

7) Manajemen risiko dibuat sesuai kebutuhan (tailored)
Manajemen risiko diselaraskan dengan konteks eksternal dan internal organisasi serta profil risikonya.

8) Manajemen risiko memperhitungkan faktor manusia dan budaya (takes human and cultural factors into account)

Manajemen risiko organisasi mengakui kapabilitas, persepsi, dan tujuan pihak- pihak eksternal dan internal yang dapat mendukung atau malah menghambat pencapaian tujuan organisasi.

9) Manajemen risiko bersifat transparan dan inklusif (transparent and inclusive) Dengan melibatkan para pemangku kepentingan, terutama pengambil keputusan, yang sesuai dan tepat waktu pada semua tingkatan organisasi, memastikan manajemen risiko tetap relevan dan mengikuti perkembangan. Keterlibatan ini juga memungkinkan pemangku kepentingan untuk cukup terwakili dan diperhitungkan sudut pandangnya dalam menentukan kriteria risiko.

10) Manajemen risiko bersifat dinamis, iteratif, dan responsif terhadap perubahan (dynamic, iterative and responsive to change)

Seiring dengan timbulnya peristiwa internal dan eksternal, perubahan konteks dan pengetahuan, serta diterapkannya pemantauan dan peninjauan, risiko-risiko baru bermunculan, sedangkan yang ada bisa berubah atau hilang.Karenanya, suatu organisasi harus memastikan bahwa manajemen risiko terus menerus memantau dan menanggapi perubahan.

II) Manajemen risiko memfasilitasi perbaikan dan pengembangan berkelanjutan organisasi (facilitates continual improvement and enhancement of the organization)

\subsection{Indikator Risiko}

Indikator risiko kunci adalah suatu peristiwa atau hal tertentu yang memberikan indikasi terjadinya suatu peristiwa risiko.

Dalam praktiknya indikator risiko kunci akan berperan sebagai suatu sistem peringatan dini (early warning system) bagi entitas.

Dalam praktik, agar dapat menjadi indikator yang 
terukur dan mudah dipantau serta dapat berperan sebagai sistem peringatan dini, indikator risiko kunci ditetapkan beserta parameter-parameternya, yang terdiri dari:

I) Ambang batas bawah (Medium Threshold), merupakan ambang batas awal yang memberikan indikasi suatu peristiwarisiko dapat terjadi dengan kemungkinan yang kecil.

2) Ambang batas atas (High Threshold), merupakan ambang maksimum yang memberikanindikasisuatu peristiwarisiko dapat terjadi dengan kemungkinan besar.

3) Satuan ukur (Value Unit) merupakan Satuan ambang batas (threshold).

\subsection{Risiko Di Rumah Sakit}

Risiko klinis adalah semua isu yang dapat berdampak terhadap pencapaian pelayanan pasien yang bermutu tinggi, aman dan efektif.

Fachmi (2007, pl)Kejadian yang tidak diharapkan (KTD) atau dalam literatur berbahasa Inggris dikenal dengan istilah adverse event adalah kondisi akibat pelayanan yangmenimbulkan rasa tidak nyaman, tidak sembuh, kecacatan bahkan kematian.

KTD pada dasarnya adalah risiko yang melekat dari tindakan pelayanan kesehatan.KTD adalah ouput dari error. Error secara garis besar terbagi dua, yaitu: human error dan organizational error. Human error sendiri dapat berasal dari faktor pasien dan faktor tenaga kesehatan. Organizational error sendiri seringkali diistilahkan sebagai system error, ataudalam konteks pelayanan kesehatan di rumah sakit diistilahkan sebagai hospital error.

Manajemen risiko rumah sakit adalah kegiatan berupa identifikasi dan evaluasi untuk mengurangi risiko cedera dan kerugian pada pasien, karyawan rumah sakit, pengunjung dan organisasinya sendiri (The Joint Commission on Accreditation of Healthcare Organizations/JCAHO).

\section{BAB III METODE PENELITIAN}

\section{I Metode Penelitian}

Penelitian ini bersifat deskriptif kualitatif, dengan mengukur peluang dan dampak dari pengurangan waktu dalam proses fisioterapi serta mengukur kebutuhan
SDM berdasarkan metode Workload Indicator of Staffing Need untuk mitigasi risiko.

\subsection{Populasi dan Teknik Penarikan Sampel}

I) Populasi penelititan adalah fisioterapis dan data medical record pasien pada tahun 2017 dengan rentang masa waktu 3 bulan sejakApril-Juni 2017

2) Teknik penarikan sampel adalah seluruh fisioterapis (4) dan data medical record sampling. Sampel penelitian medical record dengan jumlah 62 data pasien per hari

\subsection{Tempat dan Unit Penelitian}

Tempat penelitian adalah rumah sakit pada unit instalasi rehabilitasi medik

\subsection{Data dan Sumber Data}

I) Data proses fisioterapi (medical record)

2) Data peluang kejadian yang tidak diharapkan muncul (quesioner fisioterapi) 3) Data dampakproses fisioterapi (telaah medical record)

\subsection{Teknik Pengumpulan Data}

Instrumen yang digunakan adalah kuesioner kepada fisioterapis, wawancara dan observasi penatalaksanaan fisioterapi secara langsung dan melalui dokumentasi medical record

\subsection{Teknik Analisis Data}

Menampilkan data sumber tentang ketidaksesuaian penulisan data laporan proses fisioterapi sebagai gambaran kinerja fisioterapis melalui diagram risiko.

\subsection{Teknik Validitas dan Realibilitas Data}

I) Proses wawancara dengan fisioterapis dan telaah data medical record serta observasi mengacu pada PMK no 65 tahun 2015 tentang standar pelayanan fisioterapi 2) Penyebaran kuesioner kepada fisioterapis dengan formulir yang mengacu 
PMK no 65 tahun 2015 tentang standar pelayanan fisioterapi

\section{PEMBAHASAN}

\section{I Proses fisioterapi pada unit Instalasi Rehabilitasi Medik}

Tabel 4.1

Tahapan proses Fisioterapi tahun 2017

\begin{tabular}{|c|c|c|c|}
\hline & Tahapan & Kegiatan & Keterangan \\
\hline 1 & Pasien / klien & $\begin{array}{l}\text { Dokter penanggung } \\
\text { jawab pasien }\end{array}$ & Konsul ke fisioterapi \\
\hline 2 & $\begin{array}{l}\text { Rujukan } \\
\text { Fisioterapi } \\
\text { (bagian } \\
\text { fisioterapi/ } \\
\text { fisioterapis) }\end{array}$ & $\begin{array}{l}\text { Pemeriksaan: } \\
\text { Anamnesa } \\
\text { Tes khusus\& } \\
\text { Problematik: } \\
\text { Diagnosa }\end{array}$ & $\begin{array}{l}\text { Kondisi Umum, } \\
\text { Riwayat penyakit, } \\
\text { Reflex: Keseimbangan: } \\
\text { stabilitas: tonus otot: lingkup } \\
\text { gerak sendi: } \\
\text { Koordinasi: kelincahan: } \\
\text { kekuatan: kecepatan: daya } \\
\text { tahan: Gangguan } \\
\text { gerak dan aktifitas fungsional } \\
\text { sehubungan dengan kondisi } \\
\text { Stroke }\end{array}$ \\
\hline 3 & $\begin{array}{l}\text { Indikasi } \\
\text { Fisioterapi }\end{array}$ & $\begin{array}{l}\text { Rencana jenis } \\
\text { intervensi } \\
\text { (resep fisioterapi) }\end{array}$ & $\begin{array}{l}\text { Latihan: Elektrotherapy: } \\
\text { Maual therapy: Hydro } \\
\text { therapy: Actinotherapy: }\end{array}$ \\
\hline 4 & $\begin{array}{l}\text { Intervensi } \\
\text { Fisioterapi }\end{array}$ & $\begin{array}{l}\text { Pelaksanaan } \\
\text { intervensi }\end{array}$ & $\begin{array}{l}\text { Jenis intervensi terpilih: } \\
\text { Metode terapi : Dosis terapi: }\end{array}$ \\
\hline 5 & Dokumentasi & Pencatatan & $\begin{array}{l}\text { Assesmen (anamnesa) Tes } \\
\text { khusus Problematik } \\
\text { Diagnosa Rencana } \\
\text { intervensi Intervensi evaluasi }\end{array}$ \\
\hline 6 & $\begin{array}{l}\text { Administrasi \& } \\
\text { penjadwalan }\end{array}$ & Jadwal dan biaya & $\begin{array}{l}\text { Jumlah kunjungan per } \\
\text { minggu + biaya per kunjungan }\end{array}$ \\
\hline 7 & Selesai & Pulang & Sembuh, cacat, meninggal \\
\hline
\end{tabular}

\subsection{Klasifikasi Risiko Proses Fisioterapi}

Ketidakmampuan melakukan proses fisioterapi sesuai prosedur sehubungan dengan besarnya jumlah pasien di unit instalasi rehabilitasi medik Rumah Sakit X, di fokuskan pada beberapa tahap :

I) Tahap Rujukan Fisioterapi, kejadian yang tidak dikehendaki muncul meliputi;

(I) Fokus :Asesmen atau pemeriksaan dan pengukuran yang terdiri dari anamnesa, tes khusus/spesifik, problematik fisioterapi dan diagnosa

a. Sub fokus anamnesa terdiri atas:

- Pemeriksaan Kondisi umum (vital sign) tidak dilakukan oleh fisioterapis

- Telaah Riwayat penyakit

b. Sub fokus pengukuran umum dan tes khusus terdiri atas:

- Range of Motion berpeluang untuk tidak diukur dengan goniometer

- Manual Muscle Testing

- Oedema berpeluang untuk tidak diperiksa menggunakan standar ukur

- Reflex berpeluang untuk tidak diperiksa

- Nyeri berpeluang tidak dinilai

- Keseimbangan berpeluang tidak diperiksa dengan menggunakan standar pengukuran yang sesuai

- Stabilitas berpeluang tidak diukur

- Tonus Otot berpeluang tidak diperiksa

- Fleksibilitas berpeluang tidak diperiksa

- Koordinasi berpeluang tidak diperiksa dengan menggunakan standar pengukuran yang sesuai

- Daya tahan/Endurance berpeluang untuk tidak diukur

- Analisis berjalan berpeluang tidak dilakukan analisis

2) Tahap Indikasi Fisioterapi, kejadian yang tidak dikehendaki muncul meliputi;

(I) Focus Rencana jenis intervensi :

a. Sub focus penentuan jenis intervensi

- Exercise therapy / terapi latihan berpeluang dilakukan dengan waktu yang tidak memenuhi standar

- Manual therapy / terapi manual berpeluang tidak dilakukan

- Electrotherapy

- Hydrotherapy tidak dilakukan

- Actinotherapy

b. Pemilihan jenis intervensi berdasarkan kondisi pasien, alat dan waktu berpeluang dilakukan dengan mempertimbangakan lamanya waktu penggunaan alat intervensi, besar biaya, jumlah pasien 
3) Tahap Intervensi,kejadian yang tidak dikehendaki muncul meliputi;

(I) Fokus : Pelaksanaan intervensi

a. Sub fokus jenis intervensi terpilih:

- Exercise Therapy atau Terapi Latihan berpeluang dilakukan tidak menyeluruh

- Elektrotherapy

- Maual therapy tidak dilakukan mengingat waktu dan biaya

- Hydrotherapy tidak dilakukan karena alat tidak tersedia

- actinotherapy

b. Sub focus metode terapi: intermitent dan continous

c. Sub focus Dosis terapi:

Intensitas, Frekuensi berpeluang untuk dikurangi, tipe, durasi berpeluang untuk dikurangi, repetisi berpeluang untuk dikurangi

4) Tahap dokumentasi, kejadian yang tidak dikehendaki muncul meliputi;

(I) Focus : pencatatan

a. Sub focus Pencatatan hasil anamnesa

b. Sub focus Pencatatan hasil tes dan pengukuran

c. Sub focus Pencatatan problematik fisioterapi

d. Sub focus Pencatatan diagnosa fisioterapi

e. Sub focus Pencatatan rencana intervensi

f. Sub focus Pencatatan proses intervensi

g. Sub focus Pencatatan rencana evaluasi dan evaluasi

h. Sub focus Pencatatan edukasi dan home programe

5) TahapAdministrasi \& penjadwalan, kejadian yang tidak dikehendaki muncul meliputi;

(I) Focus : Jadwal \& biaya

a. Sub focus : jadwal - Pendaftaran -

Jumlah paket terapi b. Sub focus : biaya -

Jenis intervensi

- Jumlah kunjungan

\subsection{Manajemen Risiko Proses Fisioterapi}

I) Pengukuran risiko pada tahap rujukan hingga dokumentasi:

(I) berdasarkan hasil distribusi kuesioner penelitian yang dibagikan kepada empat (4 orang) responden dengan identifikasi risiko "ketidakmampuan melakukan proses pemeriksaan dan pengukuran secara lengkap oleh tenaga fisioterapis" sehingga didapatkan nilai peluang serta dampak sebagai berikut :

\section{Tabel 4.2}

Pengukuran Risiko pada Tahap pemeriksaan dan pengukuran fisioterapi

\begin{tabular}{|c|c|c|c|c|c|}
\hline \multirow{2}{*}{$\begin{array}{l}\text { Identifikasi } \\
\text { risiko }\end{array}$} & \multicolumn{2}{|l|}{ Peluang } & \multicolumn{2}{|l|}{ Dampak } & \multirow{2}{*}{$\begin{array}{l}\text { Analisis } \\
\text { risiko }\end{array}$} \\
\hline & \multicolumn{4}{|c|}{ keterangan jawaban responden } & \\
\hline \multirow{3}{*}{$\begin{array}{l}\text { Pemeriksaan dan } \\
\text { pengukuran tidak } \\
\text { dilakukan berpotensi } \\
\text { kesalahannenulisan }\end{array}$} & $\begin{array}{l}\text { Banyak } \\
\text { Responden }\end{array}$ & Peluang & Dampak & Risiko & \\
\hline & 1 & 5 & 5 & 25 & Ekstrim \\
\hline & 2 & 5 & 5 & 25 & Ekstrim \\
\hline \multirow{4}{*}{$\begin{array}{l}\text { kesalahan penulisan } \\
\text { laporan atau } \\
\text { dokumentasi } \\
\text { tidak lengkap }\end{array}$} & 3 & 5 & 5 & 25 & Ekstrim \\
\hline & 4 & 5 & 5 & 25 & Ekstrim \\
\hline & \multirow[t]{2}{*}{$\mathrm{f} / \mathrm{n}$} & 20 & 20 & 100 & \\
\hline & & 5 & 5 & 25 & \\
\hline
\end{tabular}

Data diolah sendiri, tahun 2017 Risiko:

Berpotensi terjadi risiko pengabaian atau tidak melakkukan pemeriksaan dan pengukuran fisioterapi Dampak :

laporan hasil pemeriksaan dan pengukuran fisioterapi tidak lengkap, hal ini termasuk dalam kriteria katastropik dimana pada tahap pemeriksaan dan pengukuran dilakukan untuk penentuan diagnosa serta perencanaan penanganan pasien dan tidak mencantumkan ukuran hasil pemeriksaan

Manajemen risiko (mengecilkan peluang dan dampak risiko bagi pasien);

a. mengecilkan peluang : proses pemeriksaan seharusnya menggunakan buku pemeriksaan dan alat pemeriksaan yang sesuai standar (disediakan), serta diberi waktu yang memadai untuk pemeriksaan yang tepat (waktu pemeriksaan khusus I hari sebelum intervensi) serta dituliskan hasil laporan pemeriksaan sesuai standar pelayanan, penambahan jumlah tenaga fisioterapis

b. mengecilkan dampak : hendaknya dalam melakukan proses pemeriksaan dan pengukuran memakai atau mengacu pada Prosedur Operasional Standar fisioterapi 
yang dibagikan kepada empat (4 orang) responden dengan identifikasi risiko "rencana intervensi tidak sesuai standar ", maka akan didapat perhitungan peluang serta dampak sebagi berikut:

\section{Tabel 4.3}

\section{Pengukuran risiko pada tahap diagnosa \& rencana intervensi fisioterapi}

\begin{tabular}{|c|c|c|c|c|c|}
\hline \multirow{2}{*}{$\begin{array}{l}\text { Identifikasi } \\
\text { risiko }\end{array}$} & Peluang & & Dampal & & \multirow{2}{*}{$\begin{array}{l}\text { Matrik } \\
\text { Analisis } \\
\text { risiko }\end{array}$} \\
\hline & \multicolumn{4}{|c|}{ keterangan jawaban responden } & \\
\hline \multirow{5}{*}{$\begin{array}{l}\text { Diagnosa \& } \\
\text { Rencana } \\
\text { intervensi tidak } \\
\text { sesuai, standar } \\
\text { operasional } \\
\text { prosedur }\end{array}$} & $\begin{array}{l}\text { Banyak } \\
\text { Responden }\end{array}$ & Peluang & Dampak & Risiko & \\
\hline & I & 5 & 3 & 15 & Ekstrim \\
\hline & 2 & 5 & 3 & 15 & Ekstrim \\
\hline & 3 & 5 & 3 & 15 & Ekstrim \\
\hline & 4 & 5 & 3 & 15 & Ekstrim \\
\hline \multirow[b]{2}{*}{$\begin{array}{l}\text { Berpotensi } \\
\text { terjadi kesalahan } \\
\text { intervensi \& } \\
\text { lamanya } \\
\text { kesembuhan/ } \\
\text { cacat, biaya } \\
\text { pengobatan } \\
\text { bertambah }\end{array}$} & \multirow[t]{2}{*}{$f / n$} & 20 & 12 & 60 & \\
\hline & & 3 & 5 & 15 & \\
\hline
\end{tabular}

Data diolah sendiri, tahun 2017 Risiko :

Berpotensi terjadi risiko salah menentukan diagnose \& rencana intervensi Dampak:

Penyembuhan yang lama atau kecacatan serta berpotensi terjadi risiko penambahan pembiayaan pengobatan termasuk dalam kriteria katastropik dimana pada tahap diagnosa tidak mencantumkan masalah gangguan gerak fungsional sehubungan dengan diagnosa medis atau dokter dalam bentuk dokumentasi atau penulisan terintegrasi untuk menentukan penanganan serta rencana penanganan pasien Manajemen risiko (mengecilkan peluang dan dampak risiko bagi pasien);

a. mengecilkan peluang : penulisan diagnosa harus berdasarkan gangguan gerak fungsional dan perencanaan intervensi sesuai dengan hasil pemeriksaan dan pengukuran, penambahan jumlah tenaga fisioterapis dan alat intervensi

b. mengecilkan dampak : penulisan diagnosa mencantumkan masalah gangguan gerak fungsional dan rencana intervensi seharusnya sesuai dengan keadaan atau kondisi pasien

berdasarkan hasil distribusi kuesioner penelitian yang dibagikan kepada empat (4 orang) responden dengan identifikasi risiko "intervensi tidak sesuai standar ", maka akan didapat perhitungan peluang serta dampak sebagi berikut:

\section{Tabel 4.4 \\ Pengukuran risiko pada tahap intervensi fisioterapi}

\begin{tabular}{|c|c|c|c|c|c|}
\hline \multirow{2}{*}{$\begin{array}{l}\text { Identifikasi } \\
\text { risiko }\end{array}$} & \multicolumn{2}{|l|}{ Peluang } & \multicolumn{2}{|l|}{ Dampak } & \multirow{2}{*}{$\begin{array}{l}\text { Matrik } \\
\text { Analisis } \\
\text { risiko }\end{array}$} \\
\hline & \multicolumn{4}{|c|}{ keterangan jawaban responden } & \\
\hline \multirow{2}{*}{$\begin{array}{l}\text { Jenis \& dosis } \\
\text { intervensi tidak } \\
\text { sesuai kondisi }\end{array}$} & $\begin{array}{l}\text { Banyak } \\
\text { Responden }\end{array}$ & Peluang & Dampak & Risiko & \\
\hline & I & 5 & 5 & 25 & Ekstrim \\
\hline \multirow{5}{*}{$\begin{array}{l}\text { pasien } \\
\text { Berpotensi lama } \\
\text { sembuh, cacat, } \\
\text { biaya bertambah }\end{array}$} & 2 & 5 & 5 & 25 & Ekstrim \\
\hline & 3 & 5 & 5 & 25 & Ekstrim \\
\hline & 4 & 5 & 5 & 25 & Ekstrim \\
\hline & \multirow[t]{2}{*}{$f / n$} & 20 & 20 & 100 & \\
\hline & & 5 & 5 & 25 & \\
\hline
\end{tabular}

Data diolah sendiri, tahun 2017 Risiko :

a) berpotensi risiko pengurangan waktu intervensi

b) berpotensi risiko perbedaan jenis intervensi

Dampak ; lamanya proses pengobatan, peningkatan biaya pengobatan, pasien tidak sembuh atau cacat termasuk dalam kriteria katastropik dimana pada tahap intervensi tidak dilakukan berdasarkan masalah gangguan gerak fungsional sehubungan dengan diagnosa dalam dokumentasi fisioterapi

Manajemen risiko (mengecilkan peluang dan dampak bagi pasien):

g. mengecilkan peluang : jumlah tenaga fisioterapis ditambah

h. mengecilkan dampak: pelaksanaan intervensi dan dosis sesuai kondisi pasien

(4) berdasarkan hasil distribusi kuesioner penelitian yang dibagikan kepada empat (4 orang) responden dengan identifikasi risiko "dokumentasi fisio- 
terapi tidak sesuai standar “, maka akan didapat perhitungan peluang serta dampak sebagi berikut:

\section{Tabel 4.5 \\ Pengukuran risiko pada tahap dokumentasi fisioterapi}

\begin{tabular}{|c|c|c|c|c|c|}
\hline \multirow{2}{*}{$\begin{array}{l}\text { Identifikasi } \\
\text { risiko }\end{array}$} & \multicolumn{2}{|l|}{ Peluang } & \multicolumn{2}{|c|}{ Dampak } & \multirow{2}{*}{$\begin{array}{l}\text { Matrik } \\
\text { Analisis } \\
\text { risiko }\end{array}$} \\
\hline & \multicolumn{4}{|c|}{ keterangan jawaban responden } & \\
\hline \multirow{7}{*}{$\begin{array}{l}\text { Penulisan laporan } \\
\text { hasil pemeriksaan } \\
\text { tidak sesuai } \\
\text { Berpotensi risiko } \\
\text { intervensi tidak } \\
\text { sesuai, lamanya } \\
\text { proses } \\
\text { kesembuhan, } \\
\text { gagal sebagai alat } \\
\text { perlindungan } \\
\text { hukum }\end{array}$} & $\begin{array}{l}\text { Banyak } \\
\text { Responden }\end{array}$ & Peluang & Dampak & Risiko & \\
\hline & l & 5 & 5 & 25 & Ekstrim \\
\hline & 2 & 5 & 5 & 25 & Ekstrim \\
\hline & 3 & 5 & 5 & 25 & Ekstrim \\
\hline & 4 & 5 & 5 & 25 & Ekstrim \\
\hline & \multirow[t]{2}{*}{$\mathrm{f} / \mathrm{n}$} & 20 & 12 & 100 & \\
\hline & & 5 & 5 & 25 & \\
\hline
\end{tabular}

Data diolah sendiri, tahun 2017 Risiko :

a) berpotensi terjadi risiko dokumentasi tidak lengkap

b) berpotensi terjadi risiko proses terapi dalam jangka waktu lama

c) berpotensi terjadi risiko peningkatan biaya pengobatan

d) berpotensi terjadi risiko kecacatan Dampak :

Kesalahan informasi sesama tenaga fisioterapis, tenaga medis terkait, proses penyembuhan lama atau kecacatan, penambahan biaya pengobatan.

Manajemen risiko (mengecilkan peluang dan dampak bagi pasien)

a. mengecilkan peluang : mengatur waktu pemeriksaan dan pengukuran serta penulisan laporan (dokumentasi) pada waktu terpisah dengan hari pelaksanaan intervensi dan menambah jumlah tenaga fisioterapis

b. mengecilkan dampak : penulisan laporan laporan proses fisioterapi secara lengkap sesuai prosedur operasional standar

\subsection{Diagram risiko proses fisioterapi}

\section{Diagram 4.I}

Risiko tahap pemeriksaan dan pengukuran fisioterapi

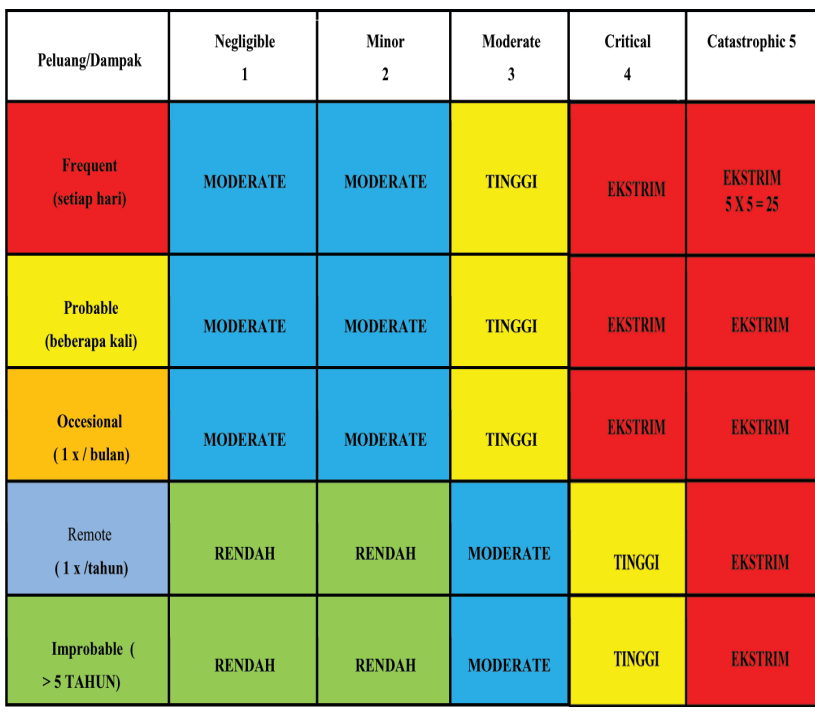

Sumber : diolah sendiri, tahun 2017

(I) Pemeriksaan dan pengukuran fisioterapi berpotensi tidak dilakukan sesuai standar operasional prosedur, sehingga berpotensi terjadi kesalahan penentuan rencana intervensi

(2) peluang kejadian : pemeriksaan dan pengukuran fisioterapi berpotensi tidak sesuai standar operasional prosedur $=5$

(3) dampak = 5 dan berpotensi terjadi kesalahan dalam menentukan rencana intervensi

(4) risiko high $=25$, sehingga risiko ini sebaiknya di hindari atau harus mendapatkan perhatian serius tentang jalan keluar yang harus dilaksanakan

(5) manajemen risiko:

a) mengecilkan peluang : diharapkan pelaksanaan proses pemeriksaan dan pengukuran sesuai dengan standar fisioterapi (kelengkapan alat pemeriksaan dan pengukuran, kecukupan waktu proses pemeriksaan dan pengukuran serta kecukupan tenaga pelaksana fisioterapi, pemisahan jadwal hari pemeriksaan dengan intervensi)

b) mengecilkan dampak : proses pemeriksaan dan pengukuran fisioterapi sesuai standar operasional prosedur 


\section{Diagram 4.2}

Risiko pada tahap diagnose \& rencana intervensi fisioterapi

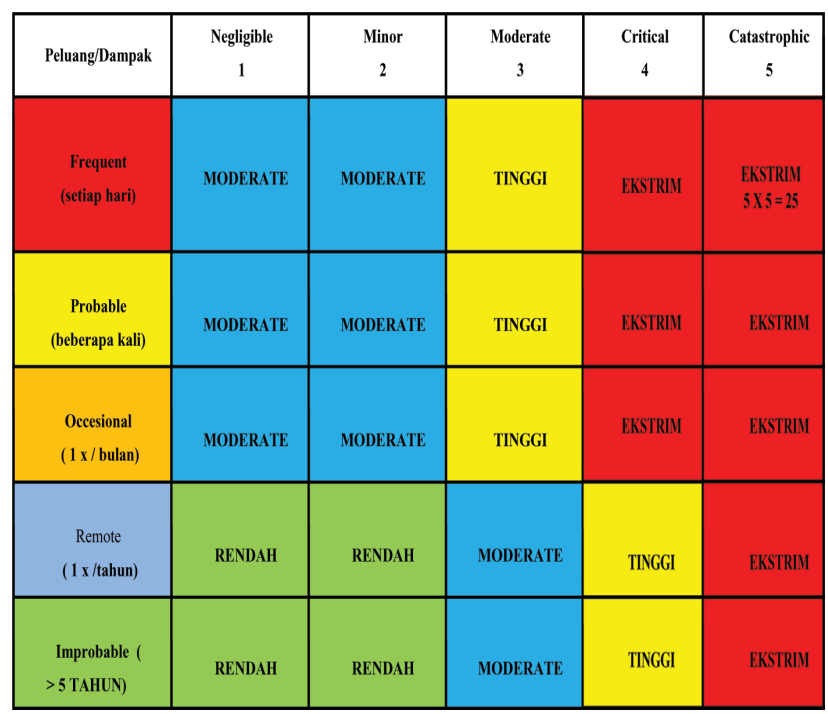

Sumber : diolah sendiri, tahun 2017

(I) Rencana Intervensi fisioterapi berpotensi tidak dilakukan sesuai kebutuhan atau kondisi pasien, sehingga berpotensi terjadi kesalahan penentuan pilihan jenis intervensi dan dosis yang akan diberikan

(2) peluang kejadian : rencana intervensi fisioterapi berpotensi tidak sesuai kebutuhan atau kondisi pasien $=3$

(3) dampak = 5 dan berpotensi terjadi kesalahan dalam menentukan jenis intervensi yang akan dilaksanakan

(4) risiko high $=15$, sehingga risiko ini sebaiknya di hindari atau harus mendapatkan perhatian serius tentang jalan keluar yang harus dilaksanakan

(5) manajemen risiko:

a) mengecilkan peluang : diharapkan pelaksanaan proses perencanaan intervensi sesuai dengan kebutuhan dan kondisi pasien (dokumen pemeriksaan yang menggambarkan ketepatan hasil pemeriksaan dan pengukuran serta diagnosa, kelengkapan alat intervensi dan kecukupan tenaga fisioterapis)

b) mengecilkan dampak : proses perencanaan intervensi fisioterapi sesuai kebutuhan dan kondisi pasien

\section{Diagram 4.3}

Risiko pada tahap intervensi fisioterapi

\begin{tabular}{|c|c|c|c|c|c|}
\hline Peluang/Dampak & Negligible 1 & Minor & $\begin{array}{c}\text { Moderate } \\
3\end{array}$ & Critical 4 & $\begin{array}{c}\text { Catastrophic } \\
5\end{array}$ \\
\hline $\begin{array}{c}\text { Frequent } \\
\text { (setiap hari) }\end{array}$ & MODERATE & MODERATE & TINGGI & EKSTRIM & $\begin{array}{c}\text { EKSTRIM } \\
5 \times 5=25\end{array}$ \\
\hline $\begin{array}{c}\text { Probable } \\
\text { (beberapa kali) }\end{array}$ & MODERATE & MODERATE & TINGGI & EKSTRIM & EKSTRIM \\
\hline $\begin{array}{c}\text { Occesional } \\
(1 \mathbf{x} / \text { bulan) }\end{array}$ & MODERATE & MODERATE & TINGGI & EKSTRIM & EKSTRIM \\
\hline $\begin{array}{c}\text { Remote } \\
(1 \mathrm{x} \text { /tahun) }\end{array}$ & RENDAH & RENDAH & MODERATE & TINGGI & EKSTRIM \\
\hline $\begin{array}{c}\text { Improbable ( } \\
\mathbf{5} \text { TAHUN) }\end{array}$ & RENDAH & RENDAH & MODERATE & TINGGI & EKSTRIM \\
\hline
\end{tabular}

(I) Pelaksanaan Intervensi fisioterapi berpotensi tidak dilakukan sesuai kebutuhan atau kondisi pasien, sehingga berpotensi terjadi proses penyembuhan yang lama, pengulangan tindakan terapi serta peningkatan biaya pengobatan peluang kejadian : pelaksanaan intervensi fisioterapi berpotensi tidak sesuai kebutuhan atau kondisi pasien $=4$

(3) dampak $=5$ dan berpotensi terjadi terjadi proses penyembuhan yang lama, pengulangan tindakan terapi serta peningkatan biaya pengobatan

(4) risiko high $=20$, sehingga risiko ini sebaiknya di hindari atau harus mendapatkan perhatian serius tentang jalan keluar yang harus dilaksanakan

(5) manajemen risiko:

a) mengecilkan peluang : diharapkan pelaksanaan intervensi sesuai dengan kebutuhan dan kondisi pasien (kelengkapan alat dan jenis intervensi, kecukupan waktu terapi serta tenaga fisioterapis), menambah jumlah alat, jenis alat dan jumlah tenaga fisioterapis

b) mengecilkan dampak : proses pelaksanaan intervensi fisioterapi sesuai kebutuhan dan kondisi pasien 


\section{Diagram 4.4}

\section{risiko pada tahap dokumentasi fisioterapi}

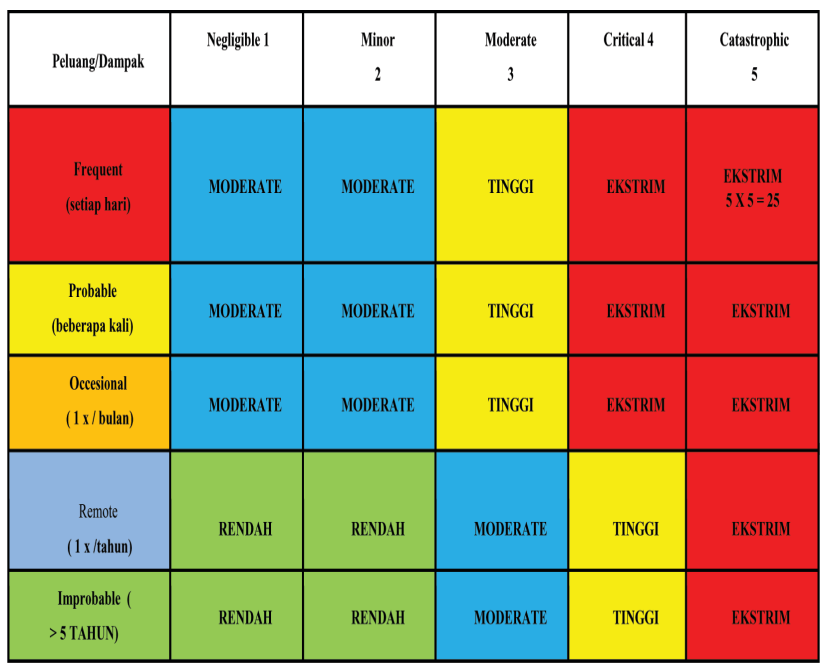

Sumber : diolah sendiri, tahun 2017

(I) Pelaksanaan dokumentasi fisioterapi berpotensi tidak ditulis secara lengkap sesuai standar penulisan data proses fisioterapi sehingga berpotensi terjadi penulisan yang tidak akurat dalam hal ukuran data hasil pemeriksaan dan pengukuran yang akan digunakan untuk menentukan rencana intervensi maupun pelaksanaan intervensi fisioterapi

(2) peluang kejadian : penulisan dokumen laporan proses fisioterapi berpotensi tidak lengkap/akurat sesuai standar penulisan dokumen proses fisioterapi $=5$

(3) dampak $=5$ dan berpotensi terjadi proses fisioterapi yang tidak sesuai dengan standar operasional prosedur

(5) manajemen risiko:

a) mengecilkan peluang : diharapkan pelaksanaan dokumentasi harus sesuai dengan tata cara penulisan dokumen fisioterapi (kelengkapan lembar dokumentasi proses fisioterapi yang disertai buku laporan hasil pemeriksaan dan pengukuran berdasarkan jenis pemeriksaan dan pengukuran fisioterapi yang dilaksanakan sebagai parameter kinerja ), pemisahan waktu pemeriksaan-pengukuran dengan waktu pelaksanaan intervensi, menambah jumlah tenaga fisioterapis

b) mengecilkan dampak : proses pelaksanaan dokumentasi fisioterapi sesuai kaidah penulisan dokumen dalam standar pelayanan fisioterapi

\subsection{Interpretasi Risiko Proses Fisioterapi di Rumah Sakit $\mathbf{X}$}

Tabel :4.6

\section{Interpretasi Risiko Proses Fisioterapi di Rumah Sakit $\mathbf{X}$}

\begin{tabular}{|c|c|c|c|c|c|}
\hline No & Identifikasi risiko & Peluang & Dampak & Risiko & $\begin{array}{l}\text { Respon } \\
\text { risiko }\end{array}$ \\
\hline 1 & $\begin{array}{l}\text { Tahap Pemeriksaan dan peng } \\
\text { ukuran fisioterapi berpotensi } \\
\text { tidak dilakukan sesuai standar } \\
\text { operasional prosedur, } \\
\text { sehingga berpotensi terjadi } \\
\text { kesalahan penentuan rencana } \\
\text { intervensi }\end{array}$ & $\begin{array}{l}20 \\
(x=5)\end{array}$ & $\begin{array}{l}20 \\
(x=5)\end{array}$ & $\begin{array}{l}100 \\
(x=25)\end{array}$ & Hindari \\
\hline 2 & $\begin{array}{l}\text { Tahap Rencana Intervensi } \\
\text { berpotensi tidak dilakukan } \\
\text { sesuai kebutuhan atau kondisi } \\
\text { pasien, sehingga berpotensi } \\
\text { terjadi kesalahan penentuan } \\
\text { pilihan jenis intervensi dan } \\
\text { dosis yang akan diberikan }\end{array}$ & $\begin{array}{l}20 \\
(x=3)\end{array}$ & $\begin{array}{l}12 \\
(x=5)\end{array}$ & $\begin{array}{l}60 \\
(x=15)\end{array}$ & Hindari \\
\hline 3 & $\begin{array}{l}\text { Tahap pelaksanaan Intervensi } \\
\text { fisioterapi berpotensi tidak } \\
\text { dilakukan sesuai kebutuhan atau } \\
\text { kondisi pasien, sehingga } \\
\text { berpotensi terjadi proses } \\
\text { penyembuhan yang lama, } \\
\text { pengulangan tindakan terapi } \\
\text { serta peningkatan biaya } \\
\text { pengobatan }\end{array}$ & $\begin{array}{l}20 \\
(x=5)\end{array}$ & $\begin{array}{l}20 \\
(x=5)\end{array}$ & $\begin{array}{l}100 \\
(x=25)\end{array}$ & Hindari \\
\hline 4 & $\begin{array}{l}\text { Pelaksanaan dokumentasi fisio } \\
\text { terapi berpotensi tidak ditulis } \\
\text { secara lengkap sesuai standar } \\
\text { penulisan data proses } \\
\text { fisioterapi sehingga berpotensi } \\
\text { terjadi penulisan yang tidak } \\
\text { akurat dalam hal data ukuran } \\
\text { hasil pemeriksaan dan } \\
\text { pengukuran yang akan } \\
\text { digunakan untuk menentukan } \\
\text { rencana intervensi maupun } \\
\text { pelaksanaan intervensi } \\
\text { fisioterapi }\end{array}$ & $(x=5)$ & $\begin{array}{l}20 \\
(x=5)\end{array}$ & $\begin{array}{l}100 \\
(x=25)\end{array}$ & Hindari \\
\hline
\end{tabular}

Sumber : diolah sendiri, tahun 2017 Keterangan : 
I. risiko (I-4) terima : sangat kecil kemungkinan terjadi kesalahan proses fisioterapi, sehingga risiko ini dapat diterima

2. risiko (5-I4) toleransi : kecil kemungkinan terjadi kesalahan proses fisioterapi, sejingga risiko ini bisa ditoleransi walaupun diwaspadai

3. risiko (I5-25) hindari : besar kemungkinan terjadi kesalahan proses fisioterapi, sehingga risiko ini sebaiknya dihindari atau harus dibuat sistim pengaturan jadwal pemeriksaan dengan jadwal intervensi serta pengadaan alat dokumentasi yang mudah untuk di aplikasikan pada setiap kondisi pasien maupun penambahan tenaga pelaksana fisioterapi

\subsection{Analisis Beban Kerja Fisioterapis}

\section{Diagram 4.5}

\section{Beban Kerja dalam Proses Fisioterapi}

a. Nomor Responden : I

b. Umur

: 5I tahun

c. JenisKelamin

: a. Laki-laki

b. Perempuan

d. Pendidikan

: a. Fisioterapi

b. Diploma (DIII),

c. Diploma (IV)

e. Unit Kerja

: Instalasi Rehabilitasi Medik

f. Ruang

: Fisioterapi

g. Lama Kerja

: 22 tahun

\begin{tabular}{|l|l|l|}
\hline Unit Kerja & Kegiatan Pokok & Rata-rata waktu \\
Klinik/poli & Tindakan fisioterapi langsung: & (Menit) \\
fisioterapi & Menerima pasien baru (anamnesa) & 7 (contoh kasus) \\
& Memberikan pemeriksaan secara & 10 (contoh kasus) \\
& individu : riwayatpenyakit, & \\
& Mengukur vital sign & 5 (contoh kasus) \\
& Inspeksi statis dan dinamis & 7 (contoh kasus) \\
& Mengukur ROM & 7 (contoh kasus) \\
& Mengukur MMT & 7 (contoh kasus) \\
& Mengukur skala Nyeri & 5 (contoh kasus) \\
& Pemeriksaan tonus & 5 (contoh kasus) \\
& Pemeriksaan stabilitas & 7 (contoh kasus) \\
& Pemeriksaan keseimbangan & 5 (contoh kasus) \\
& Pemeriksaan koordinasi & 7 (contoh kasus) \\
\hline
\end{tabular}

\begin{tabular}{|c|c|}
\hline $\begin{array}{l}\text { Pemeriksaan kecepatan } \\
\text { Pemeriksaan kelincahan } \\
\text { Pemeriksaan daya tahan } \\
\text { Pemeriksaan kelenturan } \\
\text { Pemeriksaan reflex } \\
\text { Penulisan laporan hasil pemeriksaan } \\
\text { Penentuan diagnose fisioterapi } \\
\text { Penentuan rencana tindakan fisioterapi } \\
\text { Pelaksanaan tindakan terapi Ultrasound } \\
\text { Pelaksanaan tindakan terapi Micro } \\
\text { Wave Diathermy } \\
\text { Pelaksanaan tindakan TENS } \\
\text { Pelaksanaan tindakan IR } \\
\text { Pelaksanaan tindakan manual therapy } \\
\text { Pelaksanaan tindakan stretching } \\
\text { Pelaksanaantindakanterapilathan: } \\
\text { Kasus Neuromuskuler (latihan spesifik): } \\
\text { a. Latihan keseimbangan } \\
\text { b. Latihan koordinasi } \\
\text { c. Latihan berjalan (stroke) } \\
\text { d. Latihan gerak fungsional leher, bahu, } \\
\text { lengan, tangan } \\
\text { Kasus musculoskeletal (latihan spesifik:) } \\
\text { a. latihan kekuatan } \\
\text { b. latihan lingkup gerak } \\
\text { c. latihan berjalan } \\
\text { (kasus bedah/patah tulang) } \\
\text { d. latihan stabilitas } \\
\text { Kasus Cardiovaskulopulmonal } \\
\text { (latihan spesifik): } \\
\text { a. Latihan pernapasan } \\
\text { b. Latihan daya tahan } \\
\text { (berjalan / sepeda static) } \\
\text { c. Latihan kecepatan } \\
\text { istirahat/ makan siang } \\
\text { Diskusi tenaga fisioterapi } \\
\text { (tentang pasien) } \\
\text { Mengikuti pelatihan ilmu fisioterapi } \\
\text { untuk pengembangan mutu pelayanan } \\
\text { fisioterapi }\end{array}$ & $\begin{array}{l}5 \\
5 \\
5 \\
5 \\
5 \text { (contoh kasus) } \\
3 \text { (contoh kasus) } \\
3 \text { (contoh kasus) } \\
5 \text { (contoh kasus) } \\
8 \\
15 \\
15 \\
15 \\
15 \\
10 \\
10 \text { (contoh kasus) } \\
10 \text { (contoh kasus) } \\
20 \text { (contoh kasus) } \\
15 \text { (contoh kasus) }\end{array}$ \\
\hline
\end{tabular}

Beban kerja pada kasus neuromuskuler dilihat dari lamanya waktu pelaksanaan proses fisioterapi adalah I 43 menit per pasien dengan lamanya waktu istirahat 10 menit dan 20 menit diskusi. 


\section{Diagram 4.6 Beban Kerja dalam Proses Fisioterapi}
a. Nomor Responden : 2
b. Umur
: 24 tahun
c. JenisKelamin
: a. Laki-laki
b. Perempuan
d. Pendidikan
: a. Fisioterapi
b. Diploma (DIII),
c. Diploma (IV)

e. Unit Kerja

: Instalasi Rehabilitasi Medik

f. Ruang

: Fisioterapi

g. Lama Kerja

: 2 tahun 6 bulan

\begin{tabular}{|c|c|c|}
\hline \multirow{31}{*}{$\begin{array}{l}\text { Unit Kerja } \\
\text { Klinik/poli } \\
\text { fisioterapi }\end{array}$} & Kegiatan Pokok & Rata-rata waktu \\
\hline & Tindakan fisioterapi langsung: & (Menit) \\
\hline & Menerima pasien baru (anamnesa) & 5 (contoh kasus) \\
\hline & Memberikan pemeriksaan secara & 5 (contoh kasus) \\
\hline & individu : riwayatpenyakit, & \\
\hline & Mengukur vital sign & 5 (contoh kasus) \\
\hline & Inspeksi statis dan dinamis & 3 (contoh kasus) \\
\hline & Mengukur ROM & 5-10(contohkasus) \\
\hline & Mengukur MMT & 5 (contoh kasus) \\
\hline & Mengukur skala Nyeri & 3-5 (contoh kasus) \\
\hline & Pemeriksaan tonus & 3 (contoh kasus) \\
\hline & Pemeriksaan stabilitas & 3 (contoh kasus) \\
\hline & Pemeriksaan keseimbangan & 5 (contoh kasus) \\
\hline & Pemeriksaan koordinasi & 3-5 (contoh kasus) \\
\hline & Pemeriksaan kecepatan & 5 \\
\hline & Pemeriksaan kelincahan & 5 \\
\hline & Pemeriksaan daya tahan & 10 \\
\hline & Pemeriksaan kelenturan & 5 \\
\hline & Pemeriksaan reflex & 3 \\
\hline & Penulisan laporan hasil pemeriksaan & 5-10(contohkasus) \\
\hline & Penentuan diagnose fisioterapi & 1 (contoh kasus) \\
\hline & Penentuan rencana tindakan fisioterapi & 1 (contoh kasus) \\
\hline & Pelaksanaan tindakan terapi Ultrasound & 10 (contoh kasus) \\
\hline & Pelaksanaan tindakan terapi & 15 (contoh kasus) \\
\hline & Micro Wave Diathermy & \\
\hline & Pelaksanaan tindakan TENS & 15 \\
\hline & Pelaksanaan tindakan IR & 15 \\
\hline & Pelaksanaan tindakan manual therapy & $5-15$ \\
\hline & Pelaksanaan tindakan stretching & 5-10(contohkasus) \\
\hline & Pelaksanaantindakanterapilatihan: & \\
\hline & Kasus Neuromuskuler ( latihan spesifik) & \\
\hline
\end{tabular}

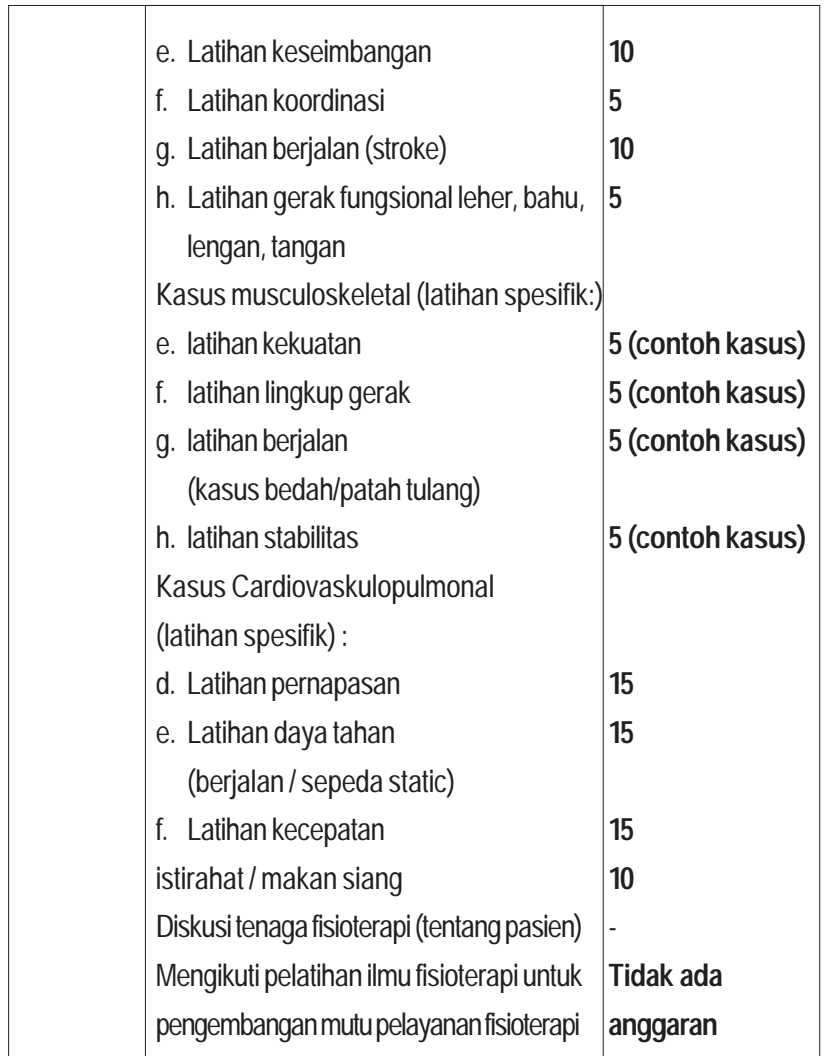

Beban kerja pada kasus mosculoskeletal dilihat dari lamanya waktu pelaksanaan proses fisioterapi adalah 102 menit per pasien dengan lamanya waktu istirahat 10 menit

\section{Diagram 4.7}

\section{Beban Kerja dalam Proses Fisioterapi}
a. Nomor Responden : 3
b. Umur
: 33 tahun
c. JenisKelamin
: a. Laki-laki
d. Pendidikan
b. Perempuan
: a. Fisioterapi
b. Diploma (DIII),
c. Diploma (IV)

e. Unit Kerja

: Instalasi Rehabilitasi Medik

f. Ruang

g. Lama Kerja

: Fisioterapi

: 6 tahun

\begin{tabular}{|l|l|l|}
\hline Unit Kerja & Kegiatan Pokok & Rata-rata waktu \\
Klinik/poli & Tindakan fisioterapi langsung: & (Menit) \\
fisioterapi & Menerima pasien baru (anamnesa) & $\mathbf{5}$ (contoh kasus) \\
\hline
\end{tabular}




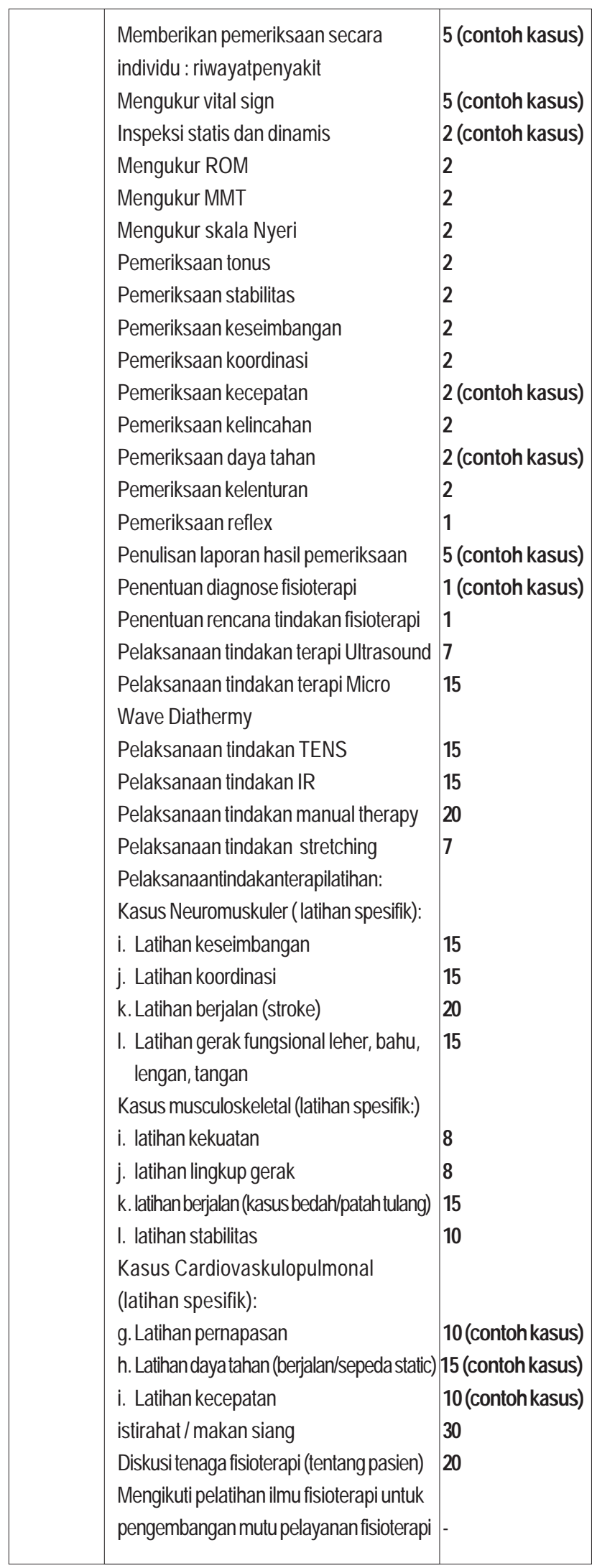

Beban kerja pada kasus Cardiovaskulopulmonal dilihat dari lamanya waktu pelaksanaan proses fisioterapi adalah 62 menit per pasien dengan lamanya waktu istirahat 30 menit, dan diskusi 20 menit.

\section{Diagram 4.8 \\ Beban Kerjadalam Proses Fisioterapi}
a. Nomor Responden : 4
b. Umur
: 23 tahun
c. JenisKelamin
: a. Laki-laki
d. Pendidikan
b. Perempuan
d. Pendidikan
: a. Fisioterapi
b. Diploma (DIII),
c. Diploma (IV)
e. Unit Kerja
: Instalasi Rehabilitasi Medik
f. Ruang
: Fisioterapi
g. Lama Kerja
: 6 bulan

\begin{tabular}{|c|c|c|}
\hline $\begin{array}{l}\text { Unit Kerja } \\
\text { Klinik/poli }\end{array}$ & $\begin{array}{l}\text { Kegiatan Pokok } \\
\text { Tindakan fisioterapi langsung : } \\
\text { Menerima pasien baru (anamnesa) } \\
\text { Memberikan pemeriksaan secara } \\
\text { individu : riwayatpenyakit } \\
\text { Mengukur vital sign } \\
\text { Inspeksi statis dan dinamis } \\
\text { Mengukur ROM } \\
\text { Mengukur MMT } \\
\text { Mengukur skala Nyeri } \\
\text { Pemeriksaan tonus } \\
\text { Pemeriksaan stabilitas } \\
\text { Pemeriksaan keseimbangan } \\
\text { Pemeriksaan koordinasi } \\
\text { Pemeriksaan kecepatan } \\
\text { Pemeriksaan kelincahan } \\
\text { Pemeriksaan daya tahan } \\
\text { Pemeriksaan kelenturan } \\
\text { Pemeriksaan reflex } \\
\text { Penulisan laporan hasil pemeriksaan } \\
\text { Penentuan diagnose fisioterapi } \\
\text { Penentuan rencana tindakan fisioterapi } \\
\text { Pelaksanaan tindakan terapi Ultrasound }\end{array}$ & $\begin{array}{l}\text { Rata-rata waktu } \\
\text { (Menit) } \\
5 \text { (contoh kasus) } \\
5 \text { (contoh kasus) } \\
5 \text { (contoh kasus) } \\
3 \text { (contoh kasus) } \\
5 \text { (contoh kasus) } \\
3 \text { (contoh kasus) } \\
2 \text { (contoh kasus) } \\
2 \text { (contoh kasus) } \\
3 \\
3 \\
3 \\
5 \\
3 \\
15 \\
2 \\
2 \\
5 \text { (contoh kasus) } \\
3 \text { (contoh kasus) } \\
2 \text { (contoh kasus) } \\
5 \text { (contoh kasus) }\end{array}$ \\
\hline
\end{tabular}




\begin{tabular}{|c|c|}
\hline Pelaksanaan tindakan terapi Micro & 15(contoh kasus) \\
\hline Wave Diathermy & \\
\hline Pelaksanaan tindakan TENS & 15 \\
\hline Pelaksanaan tindakan IR & 15 \\
\hline Pelaksanaan tindakan manual therapy & 15 \\
\hline Pelaksanaan tindakan stretching & 5 (contoh kasus) \\
\hline Pelaksanaantindakanterapilatihan: & \\
\hline Kasus Neuromuskuler & \\
\hline (latihan spesifik): & \\
\hline m. Latihan keseimbangan & 10 \\
\hline n. Latihan koordinasi & 10 \\
\hline o. Latihan berjalan (stroke) & 15 \\
\hline $\begin{array}{l}\text { p. Latihan gerak fungsional leher, } \\
\text { bahu, lengan, tangan }\end{array}$ & 5 \\
\hline Kasus musculoskeletal & \\
\hline (latihan spesifik:) & \\
\hline m. latihan kekuatan & 10 (contoh kasus) \\
\hline n. latihan lingkup gerak & 5 (contoh kasus) \\
\hline o. latihan berjalan & 10 (contoh kasus) \\
\hline (kasus bedah/patah tulang) & \\
\hline p. latihan stabilitas & 10 (contoh kasus) \\
\hline Kasus Cardiovaskulopulmonal & \\
\hline (latihan spesifik): & \\
\hline j. Latihan pernapasan & 5 \\
\hline $\begin{array}{l}\text { k. Latihan daya tahan } \\
\text { (berjalan/sepeda static) }\end{array}$ & 15 \\
\hline I. Latihan kecepatan & 5 \\
\hline istirahat/makan siang & 30 \\
\hline Diskusi tenaga fisioterapi & 5 \\
\hline (tentang pasien) & \\
\hline Mengikuti pelatihan ilmu fisioterapi & - \\
\hline untuk pengembangan mutu & \\
\hline pelayanan fisioterapi & \\
\hline
\end{tabular}

Beban kerja pada kasus Mosculoskeletal dilihat dari lamanya waktu pelaksanaan proses fisioterapi adalah 100 menit per pasien dengan lamanya waktu istirahat 30 menit, dan diskusi 5 menit.

Kesan : Berdasarkan perhitungan jumlah waktu pelaksanaan proses fisioterapi baik tindakan langsung maupun tidak langsung dari keempat responden dapat dilihat bahwa beban kerja fisioterapis berada pada kategori berat

\subsection{Observasi Kinerja melalui lembar Pemeriksaan Fisik}

\section{Diagram 4.9 \\ Analisis Pelaksanaan kinerjaFisioterapi berdasarkan tahap proses fisioterapi Responden : I}

Kinerja:

\begin{tabular}{|l|l|l|l|l|l|l|}
\hline No & Uraian & SL & SR & KD & P & T P \\
\hline 1 & Apakah fisioterapis selalu datang setiap hari & V & & & & \\
\hline 2 & Apakah fisioterapis berganti setiap hari & & & & & V \\
\hline 3 & $\begin{array}{l}\text { Apakah fisioterapis melakukan } \\
\text { pemeriksaan sebelum terapi }\end{array}$ & V & & & & \\
\hline 4 & $\begin{array}{l}\text { Apakah fisioterapis datang langsung } \\
\text { melakukan terapi }\end{array}$ & & & & & \\
\hline 5 & $\begin{array}{l}\text { Apakah fisioterapis memberi informasi } \\
\text { kemajuan terapi }\end{array}$ & & & & & \\
\hline 6 & $\begin{array}{l}\text { Apakah fisioterapis memberikan } \\
\text { laporan hasil pemeriksaan kepada pasien }\end{array}$ & & & & V \\
\hline 7 & $\begin{array}{l}\text { Apakah fisioterapis memberikan dokumen } \\
\text { laporan hasil pemeriksaan kepada pasien }\end{array}$ & & & & & V \\
\hline
\end{tabular}

Kehandalan:

\begin{tabular}{|l|l|l|l|l|l|l|}
\hline No & Uraian & SL & SR & KD & P & TP \\
\hline 1 & $\begin{array}{l}\text { Apakah fisioterapis mengutamakan } \\
\text { kenyamanan pasiensaat pemeriksaan fisik }\end{array}$ & V & & & & \\
\hline 2 & $\begin{array}{l}\text { Apakah fisioterapis menggunakan } \\
\text { alat pemeriksaan }\end{array}$ & & & & \\
\hline 3 & $\begin{array}{l}\text { Apakah fisioterapis mencatat hasil pemerik } \\
\text { saan beserta dengan nilai pengukuran dan } \\
\text { peta lokasi area yang diperiksa }\end{array}$ & & & \\
\hline 4 & $\begin{array}{l}\text { Apakah fisioterapis memberikan arahan yang } \\
\text { jelas saat pemeriksaan }\end{array}$ & & & & \\
\hline 5 & $\begin{array}{l}\text { Apakah fisioterapis menyampaikan tujuan } \\
\text { pemeriksaan (inform concern) }\end{array}$ & & & & \\
\hline 6 & $\begin{array}{l}\text { Apakah fisioterapis memberikan arahanatau } \\
\text { instruksi yang jelas saat melaksanakan } \\
\text { tindakan terapi }\end{array}$ & & & & & \\
\hline 7 & $\begin{array}{l}\text { Apakah fisioterapis mengutamakan } \\
\text { kenyamanpasiensaat pelaksanaan terapi }\end{array}$ & V & & & \\
\hline
\end{tabular}


Proses Fisioterapi

\begin{tabular}{|c|c|c|c|c|c|}
\hline No & Uraian & SL & SR & KD & $\mathbf{P}$ \\
\hline l & $\begin{array}{l}\text { Apakah Pasien membawa surat rujukan } \\
\text { dari dokter penanggungjawab ke fisioterapi }\end{array}$ & V & & & \\
\hline 2 & Apakah fisioterapis melakukan anamnesa & V & & & \\
\hline 3 & $\begin{array}{l}\text { Apakah fisioterapis melakukan } \\
\text { pemeriksaan kondisi umum }\end{array}$ & V & & & \\
\hline 4 & $\begin{array}{l}\text { Apakah fisioterapis melakukan } \\
\text { pemeriksaan riwayat penyakit }\end{array}$ & V & & & \\
\hline 5 & $\begin{array}{l}\text { Apakah fisioterapis melakukan } \\
\text { pemeriksaan reflex }\end{array}$ & & & & \\
\hline 6 & $\begin{array}{l}\text { Apakah fisioterapis melakukan } \\
\text { pemeriksan keseimbangan: } \\
\text { a. Situasi I: mata terbuka, berdiri di atas } \\
\text { permukaan yang keras } \\
\text { b. Situasi II: mata tertutup, berdiri di atas } \\
\text { permukaan yang keras } \\
\text { c. Situasi III: menggunakan penutup mata/ } \\
\text { kubah, berdiri di atas permukaan keras } \\
\text { d. Situasi IV:mata terbuka, berdiri diatas busa } \\
\text { e. Situationsi V : matatertutup, berdiri di } \\
\text { atas busa/foam } \\
\text { f. Situasi VI: menggunakan kubah penutup } \\
\text { mata,berdiri di atas busa/foam }\end{array}$ & & & & \\
\hline 7 & $\begin{array}{l}\text { Apakah fisioterapis melakukan } \\
\text { pemeriksaan stabilitas: } \\
\text { a. sendi bahu } \\
\text { b. sendi siku } \\
\text { c. sendi pergelangan tangan } \\
\text { d.sendi panggul } \\
\text { e. sendi lutut } \\
\text { f. sendi pergelangan kaki }\end{array}$ & & & & \\
\hline 8 & $\begin{array}{l}\text { Apakah fisioterapis melakukan } \\
\text { pemeriksaan tonus otot }\end{array}$ & & & V & \\
\hline 9 & $\begin{array}{l}\text { Apakah fisioterapismenuliskan nilai hasil } \\
\text { pengukuran lingkup gerak sendi }\end{array}$ & & & & \\
\hline 10 & $\begin{array}{l}\text { Apakah fisioterapismenuliskan nilai hasil } \\
\text { pengukuran kekuatan otot }\end{array}$ & & & & \\
\hline 11 & $\begin{array}{l}\text { Apakah fisioterapis melakukan } \\
\text { pemeriksaan k0ordinasi }\end{array}$ & & & & \\
\hline 12 & $\begin{array}{l}\text { Apakah fisioterapis melakukan } \\
\text { pemeriksaan kelincahan }\end{array}$ & & & & \\
\hline 13 & $\begin{array}{l}\text { Apakah fisioterapis melakukan } \\
\text { pemeriksaan kecepatan }\end{array}$ & & & & \\
\hline
\end{tabular}

\begin{tabular}{|c|c|c|c|}
\hline 14 & $\begin{array}{l}\text { Apakah fisioterapis melakukan } \\
\text { pemeriksaan daya tahan }\end{array}$ & & \\
\hline 15 & $\begin{array}{l}\text { Apakah fisioterapis menginventarisir } \\
\text { problematik pasien }\end{array}$ & & \\
\hline 16 & Apakah fisioterapis membuat diagnosa fisioterapi & & \\
\hline 17 & Apakah fisioterapis membuatrencanaevaluasi & & \\
\hline 18 & $\begin{array}{l}\text { Apakah fisioterapis membuat pemilihan } \\
\text { atau penentuan intervensi fisioterapi }\end{array}$ & V & \\
\hline 19 & $\begin{array}{l}\text { Apakah fisioterapis menentukan dosis } \\
\text { intervensi fisioterapi }\end{array}$ & V & \\
\hline 20 & $\begin{array}{l}\text { Apakah fisioterapis membuat penjelasan atas } \\
\text { penentuan atau pemilihan jenis intervensi }\end{array}$ & & \\
\hline 21 & $\begin{array}{l}\text { Apakah fisioterapis melakukan evaluasi } \\
\text { hasil intervensi fisioterapi }\end{array}$ & & \\
\hline 22 & $\begin{array}{l}\text { Apakah fisioterapis memberikan edukasi } \\
\text { fisioterapi terhadap pasien (home program) }\end{array}$ & & V \\
\hline 23 & $\begin{array}{l}\text { Apakah fisioterapis mendokumentasikan } \\
\text { data hasil pemeriksaan fisioterapi }\end{array}$ & V & \\
\hline 24 & $\begin{array}{l}\text { Apakah anda memberikan laporan hasil } \\
\text { pemeriksaan kepada pasien dalam bentuk } \\
\text { buku hasil pemeriksaan: } \\
\text { a. Kekuatan (Manual Muscle Testing) } \\
\text { b. Kecepatan (Speed) } \\
\text { c. Kelincahan (Agility) } \\
\text { d. Koordinasi (Coordination) } \\
\text { e. Daya tahan (Endurance) } \\
\text { f. Lingkup gerak sendi (Range of Motion) } \\
\text { g. Keseimbangan (Balance) } \\
\text { h. Stabilitas (Stability) }\end{array}$ & & \\
\hline 25 & $\begin{array}{l}\text { Apakah fisioterapis memberikan informasi } \\
\text { bahwa tindakan fisioterapi telah selesai }\end{array}$ & V & \\
\hline
\end{tabular}

Responden : 2 KinerjaFisioterapis :

\begin{tabular}{|l|l|l|l|l|l|l|}
\hline No & Uraian & SL & SR & KD & P & TP \\
\hline 1 & Apakah fisioterapis selalu datang setiap hari & V & & & & \\
\hline 2 & Apakah fisioterapis berganti setiap hari & V & & & & \\
\hline 3 & $\begin{array}{l}\text { Apakah fisioterapis melakukan pemeriksaan } \\
\text { sebelum terapi }\end{array}$ & & & & \\
\hline 4 & $\begin{array}{l}\text { Apakah fisioterapis datang langsung } \\
\text { melakukan terapi }\end{array}$ & & & & & V \\
\hline 5 & $\begin{array}{l}\text { Apakah fisioterapis memberi informasi } \\
\text { kemajuan terapi }\end{array}$ & & V & & & \\
\hline 6 & $\begin{array}{l}\text { Apakah fisioterapis memberikan laporan } \\
\text { hasil pemeriksaan kepada pasien }\end{array}$ & & & & & V \\
\hline 7 & $\begin{array}{l}\text { Apakah fisioterapis memberikan dokumen } \\
\text { laporan hasil pemeriksaan kepada pasien }\end{array}$ & & & & & V \\
\hline
\end{tabular}


Kehandalan Fisioterapis:

\begin{tabular}{|l|l|l|l|l|l|l|}
\hline No & Uraian & SL & SR & KD & P & TP \\
\hline 1 & $\begin{array}{l}\text { Apakah fisioterapis mengutamakan } \\
\text { kenyamananpasiensaat pemeriksaan fisik }\end{array}$ & V & & & & \\
\hline 2 & Apakahfisioterapismenggunakanalatpemeriksaan & & & V & \\
\hline 3 & $\begin{array}{l}\text { Apakah fisioterapis mencatat hasil } \\
\text { pemeriksaan beserta dengan nilai pengukuran } \\
\text { dan peta lokasi area yang diperiksa }\end{array}$ & & & & & V \\
\hline 4 & $\begin{array}{l}\text { Apakah fisioterapis memberikan arahan yang } \\
\text { jelas saat pemeriksaan }\end{array}$ & & & & \\
\hline 5 & $\begin{array}{l}\text { Apakah fisioterapis menyampaikan tujuan } \\
\text { pemeriksaan (inform concern) }\end{array}$ & & & & & \\
\hline 6 & $\begin{array}{l}\text { Apakah fisioterapis memberikan arahanatau } \\
\text { instruksi yang jelas saat melaksanakan } \\
\text { tindakan terapi }\end{array}$ & & & & & \\
\hline 7 & $\begin{array}{l}\text { Apakah fisioterapis mengutamakankenyaman } \\
\text { pasiensaat pelaksanaan terapi }\end{array}$ & & & & \\
\hline
\end{tabular}

Proses Fisioterapi

\begin{tabular}{|c|c|c|c|c|c|c|}
\hline No & Uraian & SL & SR & KD & $\mathbf{P}$ & TP \\
\hline 1 & $\begin{array}{l}\text { Apakah Pasien membawa surat rujukan } \\
\text { dari dokter penanggungjawab ke fisioterapi }\end{array}$ & V & & & & \\
\hline 2 & Apakah fisioterapis melakukan anamnesa & V & & & & \\
\hline 3 & $\begin{array}{l}\text { Apakah fisioterapis melakukan pemeriksaan } \\
\text { kondisi umum }\end{array}$ & & & & & \\
\hline 4 & $\begin{array}{l}\text { Apakah fisioterapis melakukan } \\
\text { pemeriksaan riwayat penyakit }\end{array}$ & V & & & & \\
\hline 5 & $\begin{array}{l}\text { Apakah fisioterapis melakukan } \\
\text { pemeriksaan reflex }\end{array}$ & & & & & \\
\hline 6 & $\begin{array}{l}\text { Apakah fisioterapis melakukan } \\
\text { pemeriksaan keseimbangan: } \\
\text { a. Situasi I : mata terbuka, berdiri di atas } \\
\text { permukaan yang keras } \\
\text { b. Situasi II: mata tertutup, berdiri di atas } \\
\text { permukaan yang keras } \\
\text { c. Situasi III: menggunakan penutup mata/ } \\
\text { kubah, berdiri di atas permukaan keras } \\
\text { d. Situasi IV: mata terbuka, berdiri } \\
\text { di atas busa } \\
\text { e. Situationsi V : matatertutup, berdiri } \\
\text { di atas busa/foam } \\
\text { f. Situasi VI: menggunakan kubah } \\
\text { penutup mata,berdiri diatas busa/foam }\end{array}$ & & V & & & \\
\hline
\end{tabular}

\begin{tabular}{|c|c|c|c|c|c|c|}
\hline 7 & $\begin{array}{l}\text { Apakah fisioterapis melakukan } \\
\text { pemeriksaan stabilitas: } \\
\text { a. sendi bahu } \\
\text { b. sendi siku } \\
\text { c. sendi pergelangan tangan } \\
\text { d. sendi panggul } \\
\text { e. sendi lutut } \\
\text { f. sendi pergelangan kaki }\end{array}$ & & & $\begin{array}{l}\mathrm{V} \\
\mathrm{V} \\
\mathrm{V} \\
\mathrm{V} \\
\mathrm{V} \\
\mathrm{V}\end{array}$ & & \\
\hline 8 & $\begin{array}{l}\text { Apakah fisioterapis melakukan } \\
\text { pemeriksaan tonus otot }\end{array}$ & V & & & & \\
\hline 9 & $\begin{array}{l}\text { Apakah fisioterapismenuliskan nilai hasil } \\
\text { pengukuran lingkup gerak sendi }\end{array}$ & & & & & V \\
\hline 10 & $\begin{array}{l}\text { Apakah fisioterapismenuliskan nilai hasil } \\
\text { pengukuran kekuatan otot }\end{array}$ & & & & V & \\
\hline 11 & $\begin{array}{l}\text { Apakah fisioterapis melakukan } \\
\text { pemeriksaan koordinasi }\end{array}$ & & V & & & \\
\hline 12 & $\begin{array}{l}\text { Apakah fisioterapis melakukan } \\
\text { pemeriksaan kelincahan }\end{array}$ & & & & & V \\
\hline 13 & $\begin{array}{l}\text { Apakah fisioterapis melakukan } \\
\text { pemeriksaan kecepatan }\end{array}$ & & & & & V \\
\hline 14 & $\begin{array}{l}\text { Apakah fisioterapis melakukan } \\
\text { pemeriksaan daya tahan }\end{array}$ & & & V & & \\
\hline 15 & $\begin{array}{l}\text { Apakah fisioterapis menginventarisir } \\
\text { problematik pasien }\end{array}$ & V & & & & \\
\hline 16 & Apakahfisioterapismembuatdiagnosa fisioterapi & & & V & & \\
\hline 17 & Apakah fisioterapis membuatrencanaevaluasi & V & & & & \\
\hline 18 & $\begin{array}{l}\text { Apakah fisioterapis membuat pemilihan atau } \\
\text { penentuan intervensi fisioterapi }\end{array}$ & & & V & & \\
\hline 19 & $\begin{array}{l}\text { Apakah fisioterapis menentukan dosis } \\
\text { intervensi fisioterapi }\end{array}$ & & V & & & \\
\hline 20 & $\begin{array}{l}\text { Apakah fisioterapis membuat penjelasan } \\
\text { atas penentuan atau pemilihan jenis intervensi }\end{array}$ & & & V & & \\
\hline 21 & $\begin{array}{l}\text { Apakah fisioterapis melakukan evaluasi } \\
\text { hasil intervensi fisioterapi }\end{array}$ & & & V & & \\
\hline 22 & $\begin{array}{l}\text { Apakah fisioterapis memberikan edukasi } \\
\text { fisioterapi terhadap pasien (home program) }\end{array}$ & & V & & & \\
\hline 23 & $\begin{array}{l}\text { Apakah fisioterapis mendokumentasikan } \\
\text { data hasil pemeriksaan fisioterapi }\end{array}$ & V & & & & \\
\hline 24 & $\begin{array}{l}\text { Apakah fisioterapis memberikan laporan hasil } \\
\text { pemeriksaan kepada pasien dalam bentuk } \\
\text { buku hasil pemeriksaan: } \\
\text { a. Kekuatan (Manual Muscle Testing) } \\
\text { b. Kecepatan (Speed) } \\
\text { c. Kelincahan (Agility) } \\
\text { d. Koordinasi (Coordination) } \\
\text { e. Daya tahan (Endurance) } \\
\text { f. Lingkup gerak sendi (Range of Motion) } \\
\text { g. Keseimbangan (Balance) } \\
\text { h. Stabilitas (Stability) }\end{array}$ & & & & & $\begin{array}{l}V \\
V \\
V \\
V \\
V \\
V \\
V\end{array}$ \\
\hline 25 & $\begin{array}{l}\text { Apakah fisioterapis memberikan informasi } \\
\text { bahwa tindakan fisioterapi telah selesai }\end{array}$ & V & & & & \\
\hline
\end{tabular}


Responden : 3 Kinerja:

\begin{tabular}{|l|l|l|l|l|l|l|}
\hline No & Uraian & SL & SR & KD & P & TP \\
\hline 1 & Apakah fisioterapis selalu datang setiap hari & V & & & & \\
\hline 2 & Apakah fisioterapis berganti setiap hari & & & & & V \\
\hline 3 & $\begin{array}{l}\text { Apakah fisioterapis melakukan pemeriksaan } \\
\text { sebelum terapi }\end{array}$ & & & & \\
\hline 4 & $\begin{array}{l}\text { Apakah fisioterapis datang langsung } \\
\text { melakukan terapi }\end{array}$ & & V & & & \\
\hline 5 & $\begin{array}{l}\text { Apakah fisioterapis memberi informasi } \\
\text { kemajuan terapi }\end{array}$ & & & & & \\
\hline 6 & $\begin{array}{l}\text { Apakah fisioterapis memberikan laporan } \\
\text { hasil pemeriksaan kepada pasien }\end{array}$ & & & & & \\
\hline 7 & $\begin{array}{l}\text { Apakah fisioterapis memberikan dokumen } \\
\text { laporan hasil pemeriksaan kepada pasien }\end{array}$ & & & & & \\
\hline
\end{tabular}

Kehandalan Fisioterapis

\begin{tabular}{|l|l|l|l|l|l|l|}
\hline No & Uraian & SL & SR & KD & P & TP \\
\hline 1 & $\begin{array}{l}\text { Apakah fisioterapis mengutamakan } \\
\text { kenyamanan pasien saat pemeriksaan }\end{array}$ & V & & & & \\
\hline 2 & $\begin{array}{l}\text { Apakah fisioterapis menggunakan alat } \\
\text { pemeriksaan }\end{array}$ & & & & \\
\hline 3 & $\begin{array}{l}\text { Apakah fisioterapis mencatat hasil pemerik } \\
\text { saan beserta dengan nilai pengukuran } \\
\text { dan peta lokasi area yang diperiksa }\end{array}$ & & & & & V \\
\hline 4 & $\begin{array}{l}\text { Apakah fisioterapis memberikan arahan } \\
\text { yang jelas saat pemeriksaan }\end{array}$ & & & & & V \\
\hline 5 & $\begin{array}{l}\text { Apakah fisioterapis menyampaikan tujuan } \\
\text { pemeriksaan (inform concern) }\end{array}$ & & & & & \\
\hline 6 & $\begin{array}{l}\text { Apakah fisioterapis memberikan arahan } \\
\text { atau instruksi yang jelas saat } \\
\text { melaksanakan tindakan terapi }\end{array}$ & & & & & \\
\hline 7 & $\begin{array}{l}\text { Apakah fisioterapis mengutamakan } \\
\text { kenyaman pasien saat pelaksanaan terapi }\end{array}$ & V & & & & \\
\hline
\end{tabular}

Proses Fisioterapi

\begin{tabular}{|l|l|l|l|l|l|l|}
\hline No & Uraian & SL & SR & KD & P & TP \\
\hline 1 & $\begin{array}{l}\text { Apakah Pasien membawa surat rujukan } \\
\text { dari dokter penanggungjawab ke fisioterapi }\end{array}$ & V & & & & \\
\hline 2 & Apakah fisioterapis melakukan anamnesa & V & & & & \\
\hline 3 & $\begin{array}{l}\text { Apakah fisioterapis melakukan } \\
\text { pemeriksaan kondisi umum }\end{array}$ & & V & & & \\
\hline 4 & $\begin{array}{l}\text { Apakah fisioterapis melakukan } \\
\text { pemeriksaan riwayat penyakit }\end{array}$ & & V & & & \\
\hline 5 & $\begin{array}{l}\text { Apakah fisioterapis melakukan } \\
\text { pemeriksaan reflex }\end{array}$ & & & & & \\
\hline
\end{tabular}

$6 \quad$ Apakah fisioterapis melakukan pemeriksaan keseimbangan:

a. Situasi I : mata terbuka, berdiri di atas permukaan yang keras

b. Situasi II: mata tertutup, berdiri di atas permukaan yang keras

c. Situasi III: menggunakan penutup mata/ kubah, berdiri di atas permukaan keras

d. Situasi IV: mata terbuka, berdiri di atas busa

e. Situationsi V : matatertutup, berdiri di atas busa/foam

f. Situasi Vl: menggunakan kubah penutup mata,berdiri di atas busa/foam

7 Apakah fisioterapis melakukan pemeriksaan stabilitas:

a. sendibahu

b. sendi siku

c. sendi pergelangan tangan d.sendi panggul

e. sendi lutut

f. sendi pergelangan kaki

8 Apakah fisioterapis melakukan pemeriksaan tonus otot

9 Apakah fisioterapismenuliskan nilai hasil pengukuran lingkup gerak sendi

10 Apakah fisioterapismenuliskan nilai hasil pengukuran kekuatan otot

11 Apakah fisioterapis melakukan pemeriksaan koordinasi

12 Apakah fisioterapis melakukan pemeriksaan kelincahan

13 Apakah fisioterapis melakukan pemeriksaan kecepatan

14 Apakah fisioterapis melakukan pemeriksaan daya tahan

15 Apakah fisioterapis menginventarisir problematik pasien

16 Apakah fisioterapismembuat diagnosafisioterapi

17 Apakah fisioterapis membuatrencanaevaluasi

18 Apakah fisioterapis membuat pemilihan atau penentuan intervensi fisioterapi

19 Apakah fisioterapis menentukan dosis intervensi fisioterapi

२० Apakah fisioterapis membuat penjelasan atas penentuan atau pemilihan jenis intervensi 


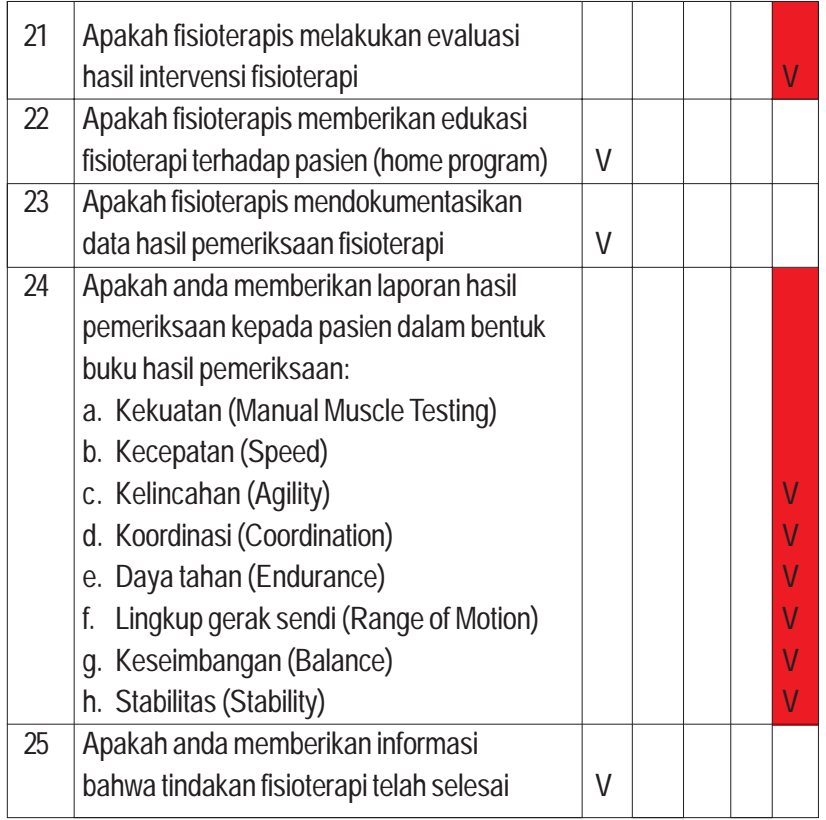

\section{Responden : 4 KinerjaFisioterapis}

\begin{tabular}{|l|l|l|l|l|l|l|}
\hline No & Uraian & SL & SR & KD & P & TP \\
\hline 1 & Apakah fisioterapis selalu datang setiap hari & V & & & & \\
\hline 2 & Apakah fisioterapis berganti setiap hari & V & & & & \\
\hline 3 & $\begin{array}{l}\text { Apakah fisioterapis melakukan } \\
\text { pemeriksaan sebelum terapi }\end{array}$ & & & & & \\
\hline 4 & $\begin{array}{l}\text { Apakah fisioterapis datang langsung } \\
\text { melakukan terapi }\end{array}$ & & & & & \\
\hline 5 & $\begin{array}{l}\text { Apakah fisioterapis memberi informasi } \\
\text { kemajuan terapi }\end{array}$ & & & & & \\
\hline 6 & $\begin{array}{l}\text { Apakah fisioterapis memberikan laporan } \\
\text { hasil pemeriksaan kepada pasien }\end{array}$ & & & & & \\
\hline 7 & $\begin{array}{l}\text { Apakah fisioterapis memberikan dokumen } \\
\text { laporan hasil pemeriksaan kepada pasien }\end{array}$ & & & & & V \\
\hline
\end{tabular}

Kehandalan Fisioterapis

\begin{tabular}{|l|l|l|l|l|l|l|}
\hline No & Uraian & SL & SR & KD & P & TP \\
\hline 1 & $\begin{array}{l}\text { Apakah fisioterapis mengutamakan } \\
\text { kenyamanan pasien saat pemeriksaan }\end{array}$ & V & & & & \\
\hline 2 & $\begin{array}{l}\text { Apakah fisioterapis menggunakan alat } \\
\text { pemeriksaan }\end{array}$ & & & & \\
\hline 3 & $\begin{array}{l}\text { Apakah fisioterapis mencatat hasil } \\
\text { pemeriksaan beserta dengan nilai pengukuran } \\
\text { dan peta lokasi area yang diperiksa }\end{array}$ & & & & & \\
\hline 4 & $\begin{array}{l}\text { Apakah fisioterapis memberikan arahan } \\
\text { yang jelas saat pemeriksaan }\end{array}$ & & & & & V \\
\hline 5 & $\begin{array}{l}\text { Apakah fisioterapis menyampaikan tujuan } \\
\text { pemeriksaan (inform concern) }\end{array}$ & & & & & \\
\hline 6 & $\begin{array}{l}\text { Apakah fisioterapis memberikan arahanatau } \\
\text { instruksi yang jelas saat melaksanakan terapi }\end{array}$ & v & & & & \\
\hline 7 & $\begin{array}{l}\text { Apakah fisioterapis mengutamakan } \\
\text { kenyaman pasien saat pelaksanaan terapi }\end{array}$ & v & & & & \\
\hline
\end{tabular}

Proses Fisioterapi

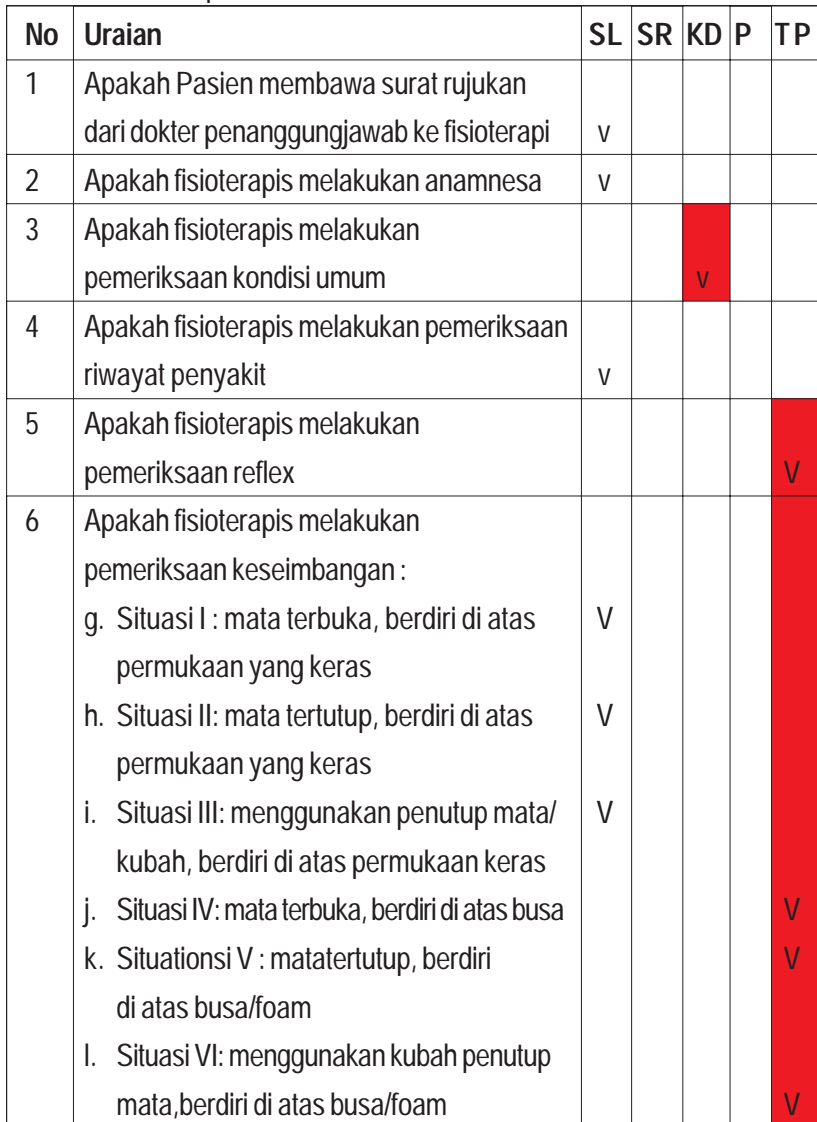

7 Apakah fisioterapis melakukan pemeriksaan stabilitas:
a. sendibahu
b. sendi siku
c. sendi pergelangan tangan
d. sendi panggul
e. sendi lutut
f. sendi pergelangan kaki

8 Apakah fisioterapis melakukan pemeriksaan tonus otot

9 Apakah fisioterapismenuliskan nilai hasil pengukuran lingkup gerak sendi

10 Apakah fisioterapismenuliskan nilai hasil pengukuran kekuatan otot

11 Apakah fisioterapis melakukan pemeriksaan koordinasi

12 Apakah fisioterapis melakukan pemeriksaan kelincahan

13 Apakah fisioterapis melakukan pemeriksaan kecepatan 


\begin{tabular}{|c|c|c|c|}
\hline 14 & $\begin{array}{l}\text { Apakah fisioterapis melakukan } \\
\text { pemeriksaan daya tahan }\end{array}$ & & \\
\hline 15 & $\begin{array}{l}\text { Apakah fisioterapis menginventarisir } \\
\text { problematik pasien }\end{array}$ & V & \\
\hline 16 & $\begin{array}{l}\text { Apakah fisioterapis membuat } \\
\text { diagnosa fisioterapi }\end{array}$ & V & \\
\hline 17 & $\begin{array}{l}\text { Apakah fisioterapis membuat } \\
\text { rencana evaluasi }\end{array}$ & & \\
\hline 18 & $\begin{array}{l}\text { Apakah fisioterapis membuat pemilihan } \\
\text { atau penentuan intervensi fisioterapi }\end{array}$ & & \\
\hline 19 & $\begin{array}{l}\text { Apakah fisioterapis menentukan dosis } \\
\text { intervensi fisioterapi }\end{array}$ & V & \\
\hline 20 & $\begin{array}{l}\text { Apakah fisioterapis membuat penjelasan } \\
\text { atas penentuan atau pemilihan jenis intervensi }\end{array}$ & & \\
\hline 21 & $\begin{array}{l}\text { Apakah fisioterapis melakukan evaluasi } \\
\text { hasil intervensi fisioterapi }\end{array}$ & V & \\
\hline २2 & $\begin{array}{l}\text { Apakah fisioterapis memberikan edukasi } \\
\text { fisioterapi terhadap pasien (home program) }\end{array}$ & V & \\
\hline 23 & $\begin{array}{l}\text { Apakah fisioterapis mendokumentasikan } \\
\text { data hasil pemeriksaan fisioterapi }\end{array}$ & & \\
\hline 24 & $\begin{array}{l}\text { Apakah anda memberikan laporan hasil } \\
\text { pemeriksaan kepada pasien dalam bentuk } \\
\text { buku hasil pemeriksaan: } \\
\text { i. Kekuatan (Manual Muscle Testing) } \\
\text { j. Kecepatan (Speed) } \\
\text { k. Kelincahan (Agility) } \\
\text { l. Koordinasi (Coordination) } \\
\text { m. Daya tahan (Endurance) } \\
\text { n. Lingkup gerak sendi (Range of Motion) } \\
\text { o. Keseimbangan (Balance) } \\
\text { p. Stabilitas (Stability) }\end{array}$ & & \\
\hline 25 & $\begin{array}{l}\text { Apakah fisioterapis memberikan informasi } \\
\text { bahwa tindakan fisioterapi telah selesai }\end{array}$ & V & \\
\hline
\end{tabular}

Keterangan :

a. Warna Merah memberikan indikasi risiko bahaya

b. Warna biru memberikan indikasi risiko kemungkinan terjadi bahaya

Hasil analisis dan observasi prosesfisioterapi pada keempat responden melalui diagram Analisis Pelaksanaan kinerja Fisioterapi berdasarkan tahap proses fisioterapi memperlihatkan bahwa penatalaksanaan fisioterapi dengan indikasi bahaya yang ditunjukkan dengan warna merah memiliki nilai sebesar $80 \%$ pada tahap proses kontak langsung dengan pasien dimana waktu yang digunakan untuk melakukan proses fisioterapi pada tahap tersebut membutuhkan waktu yang lebih lama seperti terlihat pada gambaran dalam diagram beban kerja fisioterapi bahwa beban kerja fisioterapis sudah masuk dalam kategori berat atau indikasi terjadi bahaya.

Berdasarkan perhitungan waktu dalam diagram beban kerja fisioterapi terlihat bahwa rata-rata waktu yang dibutuhkan adalah 10I,75 menit oleh seorang fisioterapis untuk melaksanakan pelayanan fisioterapi untuk satu pasien.

Waktu yang cukup lama dengan jumlah pasien 40 - 60 orang per hari, menjadi indikasi terjadi proses fisioterapi dengan risiko bahaya seperti terlihat dalam diagram analisis pelaksanaan kinerjafisioterapi berdasarkan tahap proses fisioterapi yang ditunjukkan dengan warna merah.

\subsection{Observasi Lembar Pemeriksaan Fisik Fisioterapi dan Wawancara}

\subsection{Dokumen Pemeriksaan Fisik Fisioterapi}

Penulisan laporan hasil pemeriksaan dan pengukuran tidak ditulis lengkap dengan jenis pemeriksaan serta nilai hasil pengukurannya sebelum maupun setelah terapi demikian juga dengan hasil evaluasi. Seluruh problematik fisioterapi dituliskan secara global dalam bentuk kesimpulan tanpa menulis nilaispesifik.Penulisan laporan dan dokumentasi dibuat seperti yang telah diterangkan di atas dengan asumsi bahwa semua fisioterapis telah mengetahui maksud dan tujuan penulisan, serta untuk mempersingkat waktu penulisan laporan, namun terdapat kelemahan untuk profesionalisme kerja, informasi kinerja tidak terlihat jelas, serta sarana informasi terintegrasi antar sesama tenaga medis tidak berjalan baik dan berpotensi lemah dalam menjadi alat perlindungan hukum.

\subsubsection{Pelaksanaan Intervensi Fisioterapi}

Proses pelaksanaan intervensi fisioterapi tidak dilaksanakan lengkap sesuai rencana intervensi karena dibatasi oleh kuota pembiayaan pengobatan pasien (BPJS), waktu tunggu tindakan terapi serta keberadaan fasilitas alat intervensi yang tersedia tidak sebanding dengan jumlah pasien yang membutuhkan alat yang sama dan 
juga pelaksanaan intervensi yang memakan waktu minimal I5 menit per alat.

\subsubsection{Jumlah Pasien, Jumlah Kunjungan Terapi}

Pasien yang datang untuk mendapatkan pelayanan fisioterapi $99 \%$ dari 62 medical record yang ditelaah menggunakan fasilitas Jaminan Kesehatan Nasional (BPJS). Kondisi yang terbesar adalah kasus mosculoskeletal dan pada urutan berikutnya adalah kondisi neuromuskuler, dimana kedua kondisi ini membutuhkan waktu pelayanan fisioterapi minimal 45 menit untuk pasien lama dengan masalah muskuloskeletal yang hanya menjalani terapi namun masih tetap harus dilaksanakan pemeriksaan sesaat, sedangkan untuk pasien dengan masalah neuromuskuler yang harus mendapatkan latihan lengkap membutuhkan waktu minimal 60 menit. Berbeda dengan pasien lama yang datang hanya untuk melanjutkan terapi, maka bagi pasien yang baru datang untuk pemeriksaan pertama kali maka waktu yang dibutuhkan akan lebih lama bila proses fisioterapi dilaksanakan secara lengkap sesuai standar pelayanan fisioterapi.

\subsubsection{Jumlah Pasien dan Beban Kerja Fisioterapis}

Pelayanan fisioterapi yang dilaksanakan pada unit instalasi rehabilitasi medik rumah sakit $X$ tidak dapat dilaksanakan sepenuhnya sesuai standar operasional prosedur fisioterapi sehubungan dengan beban kerja yang tinggi karena perbandingan pasien dan fisioterapis, serta fasilitas alat pemeriksaan maupun intervensni yang ada tidak seimbang.

\subsection{Workload Indicator of Staffing Need}

Perbandingan Jumlah pasien yang dilihat dalam bentuk beban kerja serta jumlah tenaga fisioterapis yang ada merupakan indikasibesarnya kebutuhan tenaga kerja dalam satu unit kerja. Berdasarkan beban kerja fisioterapi yang ada di unit instalasi rehabilitasi medik rumah sakit $X$, maka kebutuhan tenaga fisioterapis harus dihitung agar tercapai kinerja yang optimal dalam pelaksanaan pelayanan fisioterapi. Alat ukur yang digunakan untuk menganalisis kebutuhan tenaga fisioterapis adalahWISN dengan metode pengukuran menggunakan komponen atau elemen penilaian, seperti : jumlah tenaga fisioterapi yang tersedia untuk melakukan aktifitas yang dilaksanakan sebagai fisioterapis, waktu yang dibutuhkan pada tiap jenis tindakan atau aktifitas kerja fisioterapi, total waktu yang tersedia untuk setiap tenaga fisioterapis, jumlah waktu yang dibutuhkan untuk menyelesaikan tindakan yang dilaksanakan fisioterapis dan jumlah pasien serta kunjungan pasien.

Diagram 4.10

Indikator penilaian beban kerja fisioterapis untuk pasien baru

\begin{tabular}{|c|c|c|}
\hline Indikator & Pasien baru & Keterangan \\
\hline Jumlah tenaga fisioterepis & 4 & \\
\hline $\begin{array}{l}\text { Jumlah waktu tersedia } \\
\text { dalam } 1 \text { tahun }\end{array}$ & 300 menit/hari & $\begin{array}{l}270 \text { hari } \times 5 \text { jam }=1350 \times 60 \\
\text { menit }=81.000 \mathrm{mnt}\end{array}$ \\
\hline $\begin{array}{l}\text { Waktuyang dibutuhkan } \\
\text { pada tiap jenis tindakan }\end{array}$ & $\begin{array}{l}30 \text { menit } \\
45 \text { menit } \\
15 \text { menit }\end{array}$ & $\begin{array}{l}\text { Pemeriksaan, pengukuran \& } \\
\text { Rencana intervensi } \\
\text { Pelaksanaan intervensi } \\
\text { Dokumentasi proses fisioterapi }\end{array}$ \\
\hline $\begin{array}{l}\text { Total waktu untuk menye- } \\
\text { lesaikan seluruh tindakan } \\
\text { pada } 1 \text { orang pasien }\end{array}$ & 90 menit & $\begin{array}{l}\text { Intervensi alat dan latihan + } \\
\text { manual terapi }\end{array}$ \\
\hline Jumlah pasien & 10 & $\begin{array}{l}10 \text { pasien } x 90 \text { menit }= \\
900 \text { menit/hari }\end{array}$ \\
\hline
\end{tabular}

Diagram 4.11

Indikator penilaian beban kerja fisioterapis untuk pasien lama

\begin{tabular}{|l|c|l|}
\hline Indikator & Pasien lama & Keterangan \\
\hline Jumlah tenaga fisioterepis & 4 & \\
\hline $\begin{array}{l}\text { Jumlah waktu tersedia } \\
\text { Dalam 1 tahun }\end{array}$ & 300 menit/hari & $\begin{array}{l}270 \text { hari x 5 jam = } \\
1350 \times 60 \text { menit = 81.000mnt }\end{array}$ \\
\hline $\begin{array}{l}\text { Waktu yang dibutuhkan } \\
\text { pada tiap jenis tindakan }\end{array}$ & $\begin{array}{c}10 \text { menit } \\
\text { menit }\end{array}$ & $\begin{array}{l}\text { Pemeriksaan, pengukuran \& } \\
\text { Rencana intervensi } \\
\text { Pelaksanaan intervensi } \\
\text { Dokumentasi proses fisioterapi }\end{array}$ \\
\hline $\begin{array}{l}\text { Total waktu untuk menye- } \\
\text { lesaikan seluruh tindakan } \\
\text { pada 1 orang pasien }\end{array}$ & 60 menit & $\begin{array}{l}\text { Intervensi 2 alat dan latihan + } \\
\text { manual terapi }\end{array}$ \\
\hline Jumlah pasien & 50 & 50 pasien x 60 menit = \\
& & 3000 menit \\
\hline
\end{tabular}

Jumlah waktu tersedia : $312-(12+3+21+6) \times$ $5 \mathrm{jam}=1350 \times 60 \mathrm{mnt}=81.000$ menit
A : 6 hari kerja $\times 52$ minggu $=312$ hari
B : cuti tahunan $=12$ hari
C : Diklat $=3$ hari
D : Hari libur (I5) + hari cuti bersama (6) =2I hari
E : Sakit dan ijin $=6$ hari
$\mathrm{F}$ : Waktu kerja per hari $=5$ jam
Dibawah ini akan ditampilkan tabel untuk perhitungnan jumlah tenaga fisioterapis yang dibutuhkan : 
Tabel 4.7

KESIMPULAN PERHIITUNGAN JUMLAH SDM YANG DIBUTUHKAN

\begin{tabular}{|c|c|c|c|c|c|c|}
\hline $\begin{array}{l}\text { Unit Kerja } \\
\text { Klinik/poli }\end{array}$ & $\begin{array}{l}\text { Kegiatan Pokok } \\
\text { Tindakan fisioterapi langsung : }\end{array}$ & $\begin{array}{l}\text { Rata-rata waktu } \\
\text { (Menit) }\end{array}$ & kuantitas & SBK & SK & $\begin{array}{l}\text { Kebutuhan } \\
\text { SDM }\end{array}$ \\
\hline & $\begin{array}{l}\text { Menerima pasien (anamnesa) } \\
\text { Memberikan pemeriksaan secara individu : riwayat penyakit } \\
\text { Mengukur vital sign } \\
\text { Inspeksi statis dan dinamis } \\
\text { Mengukur ROM } \\
\text { Mengukur MMT } \\
\text { Mengukur skala Nyeri } \\
\text { Pemeriksaan tonus } \\
\text { Pemeriksaan stabilitas } \\
\text { Pemeriksaan keseimbangan } \\
\text { Pemeriksaan koordinasi } \\
\text { Pemeriksaan kecepatan } \\
\text { Pemeriksaan kelincahan } \\
\text { Pemeriksaan daya tahan } \\
\text { Pemeriksaan kelenturan } \\
\text { Pemeriksaan reflex } \\
\text { Penulisan laporan hasil pemeriksaan } \\
\text { Penentuan diagnose fisioterapi } \\
\text { Penentuan rencana tindakan fisioterapi } \\
\text { Pelaksanaan tindakan terapi Ultrasound } \\
\text { Pelaksanaan tindakan terapi Micro Wave Diathermy } \\
\text { Pelaksanaan tindakan TENS } \\
\text { Pelaksanaan tindakan IR } \\
\text { Pelaksanaan tindakan manual therapy } \\
\text { Pelaksanaan tindakan stretching } \\
\text { Pelaksanaantindakanterapilatihan: } \\
\text { Kasus Neuromuskuler ( latihan spesifik) : } \\
\text { a. Latihan keseimbangan } \\
\text { b. Latihan koordinasi } \\
\text { c. Latihan berjalan (stroke) } \\
\text { d. Latihan gerak fungsional leher, bahu, lengan, tangan } \\
\text { Kasus musculoskeletal (latihan spesifik: ) } \\
\text { a. latihan kekuatan } \\
\text { b. latihan lingkup gerak } \\
\text { c. latihan berjalan (kasus bedah/patah tulang) } \\
\text { d. latihan stabilitas } \\
\text { Kasus Cardiovaskulopulmonal (latihan spesifik): } \\
\text { a. Latihan pernapasan } \\
\text { b. Latihan daya tahan (berjalan / sepeda static) } \\
\text { c. Latihan kecepatan } \\
\text { istirahat/ makan siang } \\
\text { Diskusi tenaga fisioterapi (tentang pasien) } \\
\text { Mengikuti pelatihan ilmu fisioterapi untuk pengembangan } \\
\text { mutu pelayanan fisioterapi } \\
\text { a }\end{array}$ & $\begin{array}{c}5 \text { (contoh kasus) } \\
5 \text { (contoh kasus) } \\
5 \text { (contoh kasus) } \\
3 \text { (contoh kasus) } \\
5 \text { (contoh kasus) } \\
3 \text { (contoh kasus) } \\
2 \text { (contoh kasus) } \\
2 \text { (contoh kasus) } \\
3 \\
3 \\
3 \\
5 \\
3 \\
15 \\
2 \\
2 \\
5 \text { (contoh kasus) } \\
3 \text { (contoh kasus) } \\
2 \text { (contoh kasus) } \\
5 \text { (contoh kasus) } \\
15 \text { (contoh kasus) } \\
15 \\
15 \\
15 \\
5 \text { (contoh kasus) } \\
\\
10 \text { (contoh kasus) } \\
5 \text { (contoh kasus) } \\
10 \text { (contoh kasus) } \\
10 \text { (contoh kasus) } \\
\\
5 \\
10 \\
10 \\
15 \\
20 \\
5 \\
- \\
\end{array}$ & $\begin{array}{l}10800 \\
10800 \\
10800 \\
10800 \\
5400 \\
5400 \\
5400 \\
5400 \\
2700 \\
5400 \\
5400 \\
2700 \\
2700 \\
2700 \\
2700 \\
5400 \\
10800 \\
5400 \\
5400 \\
10800 \\
10800 \\
5400 \\
5400 \\
2700 \\
2700\end{array}$ & $\begin{array}{c}16200 \\
16200 \\
16200 \\
27000 \\
16200 \\
27000 \\
40.500 \\
40.500 \\
27000 \\
27000 \\
27000 \\
16200 \\
27000 \\
5400 \\
40500 \\
40500 \\
16200 \\
27000 \\
40500 \\
16200 \\
5400 \\
5400 \\
5400 \\
5400 \\
16200\end{array}$ & $\begin{array}{l}0,0044 \\
0,0044 \\
0,0044 \\
0,0044 \\
0,0044 \\
0,0044 \\
0,0044 \\
0,0044 \\
0,0044 \\
0,0044 \\
0,0044 \\
0,0044 \\
0,0044 \\
0,0044 \\
0,0044 \\
0,0044 \\
0,0044 \\
0,0044 \\
0,0044 \\
0,0044 \\
0,0044 \\
0,0044 \\
0,0044 \\
0,0044 \\
0,0044\end{array}$ & $\begin{array}{l}0,6711 \\
0,6711 \\
0,6711 \\
0,4044 \\
0,3377 \\
0,2044 \\
0,1377 \\
0,1377 \\
0,1044 \\
0,2044 \\
0,2044 \\
0,1711 \\
0,1044 \\
0,5044 \\
0,0711 \\
0,1377 \\
0,6711 \\
0,2044 \\
0,1377 \\
0,6711 \\
2,0044 \\
1,0044 \\
1,0044 \\
0,5044 \\
0,1711\end{array}$ \\
\hline & \multicolumn{5}{|l|}{ TOTAL SDM } & 16,752 \\
\hline
\end{tabular}


Berdasarkan metode WISN yang membagi antara lamanya waktu melakukan aktifitas dengan jumlah waktu tersedia untuk tenaga pelaksanan serta dibandingkan dengan jumlah pasien dan mengacu pada Peraturan Menteri Kesehatan No. 65 Tahun 2015, tentang standar pelayanan fisioterapi, bahwa berdasarkan analisis beban kerja dan/atau rasio pelayanan pasien/klien per hari kerja (I fisioterapis : 810 pasien/klien per hari kerja) dengan asumsi waktu kerja yang disediakan adalah 8 jam per hari dan I jam proses fisioterapi untuk I orang pasien. Apabila dilihat dari data pada diagram indikator berdasarkan metode WISN lalu dilakukan perhitungan berdasarkan rumus, dengan mencantumkan total jumlah pasein 40 orang per hari dalam I tahun (rata-rata kunjungan), maka didapat hasil bahwa kebutuhan tenaga fisioterapis per hari adalah 16,75 H" 17 orang, pada unit rehabilitasi medik, Rumah Sakit X.

Berdasarkan hasil telaah penulisan dosis waktu intervensi pada kartu pasien yang dibandingkan dengan teori tentang waktu penggunaan alat intervensi fisioterapi maka dapat dilihat perbedaan yang cukup besar pada pelaksanaan intervensi dengan alat, mulai dari persiapan, tes alat sampai intervensi, begitu juga halnya dengan pemberian latihan gerak, dan masing masing mengalami pengurangan waktu selama proses sebesar rata-rata selama I 5 sampai 20 menit. Hal ini terjadi untuk mengatasi seluruh kebutuhan pasien dalam jangka waktu yang relatif singkat (5 jam kerja per hari).

Setelah melihat dari tabel dan diagram risiko yang didapat dari hasil wawancara, kuesioner serta telaah medical record pasien dan observasi sarana alat intervensi maka didapat angka yang menunjukkan potensi risiko (berkisar I5-25) dalam proses fisioterapi dengan interpretasi adanya pengaruh jumlah pasien/beban kerja terhadap proses fisioterapi. Demikian juga halnya dengan hasil yang ditunjukkan pada tabel kesimpulan perhitungan kebutuhan SDM didapat hasil berupa jumlah tenaga fisioterapi yang dibutuhkan di unit rehabilitasi medik Rumah Sakit X, dengan interpretasi adanaya kebutuhan penambahan jumlah tenaga fisioterapi, demikian juga untuk sarana alat fisioterapi yang dicantumkan dalam PMK no. 65 Tahun 2015 untuk Rumah Sakit tipe B serta diagram beban kerja terlihat adanya kebutuhan penambahan sarana alat intervensi fisioterapi.

\section{BAB V KESIMPULAN DAN SARAN}

\section{I Kesimpulan Hasil Penelitian}

I). Berdasarkan identifikasi Proses fisioterapi maka tahap kerja fisioterapi terdiri atas: Pemeriksaan dan pengukuran, diagnosa dan rencana intervensi, intervensi, evaluasi dan dokumentasi.

2). Berdasarkan identifikasi kejadian yang tidak diharapkan muncul pada proses fisioterapi, maka pada tahap Pemeriksaan \& pengukuran didapat peluang tidak melakukan pemeriksaan dan pengukuran fisioterapi karena waktu tidak memadai, pada tahap diagnosa dan rencana intervensi didapat peluang kesalahan diagnosa dan rencana pemilihan jenis intervensi, pada tahap intervensi terdapat peluang kesalahan jenis intervensi dan dosis terapi, pada tahap evaluasi dan dokumentasi terdapat peluang kesalahan penulisan informasi hasil proses fisioterapi dan evaluasi.

3). Berdasarkan pengukuran risiko maka pada tahap pemeriksaan dan pengukuran didapat nilai peluang tidak melaksanakan pemeriksaan dan pengukuran 5 dan dampak kesalahan penulisan laporan proses fisioterapi 5 dengan angka risiko 25 (tinggi) sedangkan pada tahap intervensi didapat peluang pengurangan jenis dan waktu intervensi 5 dan dampak proses kesembuhan yang lama atau tidak sembuh 5 dengan nilai risiko 25 (tinggi).

4). Berdasarkan perhitungan risiko proses fisioterapi serta Workload Indicator Staffing Need maka kebijakan mitigasi yang dilakukan adalah menambah tenaga fisioterapi sebanyak 13 orang, pengaturan hari pemeriksaan dan penambahan alat intervensi.

\subsection{Saran}

I). Rumah Sakit membuat alokasi hari khusus atau berbeda pada setiap kunjungan pertama pasien baru untuk proses pemeriksaan dan pengukuran fisioterapi serta dokumentasi dengan hari pelaksanaan intervensi.

2). Rumah Sakit menambah jumlah tenaga fisioterapis dan alat fisioterapi

3). Rumah sakit menambah atau membuka jam pelayanan kedua.

4). Rumah sakit membuat buku panduan dan laporan hasil pemeriksaan fisioterapi bagi pasien. 


\section{Referensi}

American Physical Therapy Association Department of Physical Therapy,

August 2009, Physical Therapist Assistant Clinical Performance Instrument, Education I I I I North Fairfax Street Alexandria, Virginia 22314

Behrens B, Michlovitz S, 2006, Physical Agents: Theory and Practice, 2nd ed. Philadelphia, PA: FA Davis Company

Benhard R. L. Paruntu I) A.J.M. Rattu 2) C.R.Tilaar 3), Perencanaan

Kebutuhan Sumber Daya Manusia di Puskesmas Kabupaten Minahasa

Crouhy, Galai dan Mark , 200 I, Risk Management, McGraw-Hill Education

Djojosoedarso, 2003, Prinsip-Prinsip Manajemen Risiko dan Asuransi, edisi revisi, Jakarta Salemba Empat

Djohanputro, B, 2008, Manajemen Risiko Korporat, Pendidikan dan Pembinaan Manajemen, Jakarta, Analisis Risiko Operasional Pada PT Karisma Teknika Citeurep

Gunawan \& Waluyo, (20I5), Risk Based Behavioral Savety, Penerbit Gramedia Pustaka Utama

Guspianto, 2012, Analisis Penyusunan Rencana Kebutuhan Sumber Daya Manusia Kesehatan Puskesmas di Kabupaten Muaro Jambi, Prosiding Seminar Nasional Kesehatan Jurusan Kesehatan Masyarakat FKIK UNSOED Purwokerto

Hanafi 2009, Handoko, T. Hani. 2008 Analisis Laporan Keuangan, edisi 4. UPP STIM YKPN. Yogyakarta

Ilyas, Yaslis. 2004. Perencanaan SDM Rumah Sakit, Teori, Metoda dan Formula. Depok: UI.

Lam, J, 2007, Enterprise Risk Managements, Penerbit PT. Ray

Manurung A, H, 20I4, Pengukuran Risiko, Penerbit PT. Adler Manurung Press

Manulang, 1974, Manajemen Personalia, Aksara Baru, Jakarta

Ali, M, 2006, Manajemen Risiko, Strategi Perbankan dan Dunia Usaha. Menghadapi Tantangan Globalisasi Bisnis, USU

Krisna, M 2012, Analisis Beban Kerja dan Kebutuhan Tenaga di Instalasi Farmasi Rumah Sakit Jiwa Daerah Provinsi Lampung Tahun 2012, Fakultas Kesehatan Masyarakat Program Kajian Administrasi Rumah Sakit

Universitas Indonesia, Depok

Kolber, M, Lucado, A, M (2005) "Risk management strategies in physical therapy: documentation to avoid malpractice", International Journal of Health Care Quality Assurance, Vol. I 8Iss:2,pp. I 23-130

Mulyawan 2015, Manajemen Keuangan, Pustaka Setia

Muslich, 2007, Risk Management, Analisis Risiko Operasional Elex Media Komputindo, Jakarta

Nadief K, 2010, Manajemen Risiko Terapan, Penerbit PT. Prima Pundi Redana

Parjoto S, 2006, Terapi Listrik Untuk Modulasi Nyeri, Ikata Fisioterapi Indonesia Cabang Semarang

Putri J, I, Jabbar, A, Rambe, M, 2, Wahyuni, D², 20I4, Analisis Kebutuhan Tenaga Perawat Berdasarkan Beban Kerja Dengan Menggunakan

MetodeWorkload Indicator Staff Need (WISN) DanWork Sampling,eJurnal Teknik Industri FT USUVol 5, No. 2, Maret 2014 pp. $22-25$

Samsudin, 2006, Manajemen Sumber Daya Manusia, Pustaka Setia, Bandung

Andini, S, 20 I 3,Analisa Kebutuhan Tenaga Keperawatan di Instalasi Hemodialisa Rumah Sakit Umum Pusat Persahabatan Berdasarkan Beban dan Kompetensi Kerja, Fakultas Kesehatan
Masyarakat Program Studi Kajian Administrasi Rumah Sakit, Universitas Indonesia, Depok

Shmuel Springer,Yocheved Laufer, and Michal Elboim-Gabyzonlsr, 2015, Clinical decision making for using electro-physical agents by physiotherapists, an Israeli surveyJ Health Policy Res. 2015; 4: 14. Published online 2015 Jun I5

Sigarlaki, H.J.O, 2009, Metodologi Penelitian Kedokteran dan Kesehatan, Edisi 2, CV. Infomedika, Jakarta

Sunaryo, T, 2007, Manajemen Risiko Finansial, Penerbit Salemba Empat

Teasell RI, McRae M, Foley N, Bhardwaj A, The incidence and consequences of falls in stroke patients during inpatient rehabilitation: factors associated with high risk.Copyright 2002 by the American Congress of Rehabilitation Medicine and the American Academy of Physical Medicine and Rehabilitation

Tsur AI, Segal Z, Falls in stroke patients: risk factors and risk management, Isr Med Assoc J. 2010 Apr;12(4):216-9

World Health Organization 2016, Workload indicators of staffing need (WISN): selected country implementation experiences, (Human Resources for Health Observer, 15), World Health Organization, 20 Avenue Appia, I 2 I I Geneva 27, Switzerland

World Health Organization 2010, Software Manual Workload Indicators of Staffing Need, Multilingual version, 2.2.169.1,World Health Organization, 20 Avenue Appia, I2I I Geneva 27, Switzerland

Winarti, W 2015, Hubungan Beban Kerja Perawat Dengan Pelaksanaan Dan Pendokumentasian Asuhan Keperawatan Di ICURS PKU Muhammadiyah Yogyakarta

Helianty, Y, 20I4Analisis Kebutuhan Jumlah Pegawai Berdasarkan Analisis Beban Kerja

Yocheved Laufer, and Michal Elboim-Gabyzon, 20I5, Clinical decision making for using electro-physical agents by physiotherapists, an Israeli survey

Shmuel Springer, Isr J Health Policy

Ikatan Fisioterapi Indonesia, 20I4, Standar Operasional Prosedur Fisioterapi,

Ikatan Fisioterapi Indonesia, 20 I6, Kode Etik Pelayanan Fisioterapi, Kemenkes tahun 20 I3, Laporan Riset Kesehatan Dasar (Riskesdas)

Keputusan Menteri Kesehatan Nomor:8I/ MENKES/ SK/ 2004 tentang Pedoman Penyusunan Perencanaan SDM Kesehatan

Permenkes No. 169I tahun 20II tentang: Keselamatan Pasien Rumah Sakit dan Rumah Sakit wajib melaksanakan dan wajib membentuk Tim KPRS

PMK No. 65 tahun 2015, tentang standar pelayanan fisioterapi

PMK No. 80 tahun 20I3, tentang Penyelenggaraan Pekerjaan dan Praktik Fisioterapis

RSU UKI tahun 2012 - 2014, 2014 s/d 2017, Program Mutu dan Keselamatan Pasien Rumah Sakit

SK Direksi RSU UKI No: 32/SK/Dirut/RSUUKI / 0.20 I I: tentang pembentukan

Tim Mutu dan Keselamatan Pasien Rumah Sakit (KPRS) di RSU UKI SK Direksi RSU UKI No: 050/SK/Dirut/RSUUKI /07.2013 + Add

UU No. 44 tahun 2009, tentang Rumah Sakit Pasal 43, Wajib menerapkan standar keselamatan pasien

Departemen Kesehatan Republik Indonesia dan Deutsche Gesellschaft für Technische Zusammenarbeit 2009, Perlengkapan Kerja WISN (Workload Indicators of Staffing Need)

Depkes. 2004. Pedoman Penyusunan SDM Kesehatan Di Tingkat Propinsi, Kab/Kota serta Rumah Sakit. Jakarta: Depkes 